\title{
A LIVRE CONCORRÊNCIA E O ABUSO DE PODER ECONÔMICO NA ERA DA ECONOMIA GLOBAL
}

\author{
Pollyana Cibele Pereira Costa \\ Graduada em Tecnologia em Comércio Exterior pelo Instituto Federal de Educação, \\ Ciência e Tecnologia do Rio Grande do Norte. Acadêmica do curso de Direito da \\ Universidade Estadual do Rio Grande do Norte. \\ E-mail: pollyanacosta88@ hotmail.com \\ Eduardo Janser de Azevedo Dantas
}

Graduado em Engenharia Elétrica pela Universidade Federal do Rio Grande do Norte, graduado em Ciências Econômicas pela Universidade Federal do Rio Grande do Norte e mestrado em Engenharia Elétrica pela Universidade Federal do Rio Grande do Norte.

E-mail: eduardojanser@yahoo.com.br.

\begin{abstract}
RESUMO
O liberalismo econômico tem fomentado a ação indiscriminada dos agentes econômicos no âmbito do mercado. As distorções advindas de tal cenário suscitaram a necessidade da atuação estatal através da instituição de normas reguladoras que viessem a limitar a atuação destes agentes, a fim de se minimizar as distorções que o poder econômico inerente a estes acabam por deflagrar. Nesta perspectiva o presente trabalho, utilizando-se da metodologia exploratório descritiva, tem por finalidade analisar o princípio constitucional da livre concorrência, suscitando os pressupostos que a encerram e faz adentrar na manifestação abusiva do poder econômico, levantando o ordenamento jurídico pátrio que tutela a concorrência, traçando ainda um paralelo entre este e o nível de regulação internacional, concluindo pela intelecção de que na legislação brasileira já se verifica grande avanço nesta seara, dada a elucidação da lei 8884/94 que traz consigo os pressupostos a serem observados no caso concreto a fim de que se identifique a manifestação abusiva do poder econômico, o que, entretanto, não se tem alcançado ainda a nível internacional.
\end{abstract}

PALAVRAS-CHAVE: Regulação, Livre concorrência, Abuso de poder econômico, Lei $8884 / 94$

\section{FREE COMPETITION AND ECONOMIC ABUSE OF POWER IN THE AGE OF GLOBAL ECONOMY}

\begin{abstract}
The economic liberalism has encouraged the indiscriminate action of economic agents within the market. These wrong action resulting from such a situation raised the need for state action through the establishment of rules that would limit the activities of these agents in order to minimize the distortion that the economic power inherent in these show end up. In this perspective the present work, using the descriptive exploratory methodology, aims to examine the constitutional principle of free competition, raising the purposes that is close and enter in the demonstration of economic power abuse, raising the legal mother who terminating the guardianship of the competition, making even a parallel between this and the level of international regulation, concluding that the intellection of Brazilian law there is already great progress in this area, by the elucidation of the law 8884/94 which
\end{abstract}


brings the conditions to be observed in this case to identify the event that misuse of economic power, which, however, has not yet reached the international level.

Key Words: Regulation, Free competition, Abuse of economic power, Law 8884/94.

\section{ESCREVA AQUI O TÍTULO DO TRABALHO, UTILIZANDO FONTE TIMES NEW ROMAN, CORPO 12, ALINHADO AO CENTRO, MAIÚSCULA, NEGRITO}

\section{INTRODUÇÃO}

O advogado e sociólogo Liszt Vieira, na obra Cidadania e Globalização, (2000, p. 80), dispõe num ímpeto de irretocável lucidez, que "os agentes mais dinâmicos da globalização não são os governos que formaram mercados comuns em busca da integração econômica, mas os conglomerados e empresas transnacionais que dominam a maior parte da produção, do comércio, da tecnologia, e das finanças internacionais".

Os pressupostos que corroboram a tese do mestre se perfazem na observância fática de que o mercado tornou-se a matriz estruturadora da vida social e política da humanidade sobrepondo-se às fronteiras nacionais. $\mathrm{O}$ comando da economia global encontra-se maciçamente atrelado aos tentáculos das grandes corporações e não absolutamente do governo tal qual preconiza Vieira. O poder econômico a elas inerente garante a preponderância de seus ditames acerca dos elementos inerentes à ordem econômica, como o câmbio, a taxa de juros, o rendimento da poupança, dos investimentos, preços de commodities etc.

Tal hegemonia, conseguintemente, tem reflexos diretos na vida social e perniciosos efeitos no âmbito do mercado haja vista que a predominância de certos agentes econômicos gozando de desmesurado poder econômico acaba por dirimir, limitar e inviabilizar a atuação livre dos demais agentes detentores de inferior poder econômico no seio do mercado, dada a inobservância de condições minimamente viáveis de concorrência.

$\mathrm{Na}$ persecução analítica do contraponto retro descrito se vivifica a ainda incipiente compreensão do quão patológico se torna a atuação livre dos agentes econômicos quando acaba por enveredar no exercício arbitrário do poder econômico. Assim, faz-se cabível a escorreita aferição do tênue limite o qual encerra a atuação econômica livre e adentra a esfera do abuso de poder econômico, sendo este o alvo de análise da presente pesquisa, tendo em vista a crescente visualização fática de casos os quais suscitam tal compreensão.

Deste modo a presente pesquisa intenta a obstinada análise do que seja a livre concorrência e o abuso do poder econômico a fim de que tal intelecção permita que nos casos concretos se possa identificar a mera manifestação da livre atuação no mercado ou que se deflagre a conduta abusiva pressuposto do poder econômico do agente, de forma que se proceda à efetiva atuação estatal no intuito repressivo e sancionador que lhe é atributo.

Eis que nesta análise o Direito e a Economia se imiscuem somando préstimos os quais reunidos evocam a objetiva intelecção dos fenômenos em estudo, de maneira que reunidas elementares de ambos os ramos científicos tem-se a efetiva formulação dos elementos a se observar na manifestação destes fenômenos a fim de que se persiga a efetiva compreensão que os casos concretos demandam. 
Assim o presente estudo evocará a análise dos fenômenos tendo por base o arcabouço normativo nacional, suscitando ainda organizações e elementos de ordem internacional a fim de se traçar um paralelo entre estes e de se deflagrar o estágio regulatório atual no qual se encontra a disciplina da tutela da concorrência posto que se trata de um fenômeno manifestamente de ordem global.

Sobre tal perspectiva a pesquisa se dará mediante utilização do método bibliográfico a partir do qual será baseado em dados correlatos à temática oriundos de artigos, livros, trabalhos acadêmicos e páginas da web as quais detenham conteúdo pertinente ao proposto neste trabalho, bem como no método exploratório-descritivo uma vez que observar-se-á o levantamento de informações acerca do objeto estudado na persecução de sua caracterização.

Dentro deste cenário revela-se primordial o prévio levantamento analítico da composição estrutural do mercado que é, pois, o ponto de partida do presente estudo.

\section{A TEORIA MICROECONÔMICA E AS ESTRUTURAS DE MERCADO}

A Teoria Microeconômica é aquela a qual centra-se na análise comportamental das unidades econômicas individuais na figura dos consumidores e das empresas objetivando a persecução do relacionamento entre estes agentes a fim de que se deflagre o processo de formação de preços no âmbito dos mercados, sendo a análise da demanda e da oferta o ponto inicial do qual se delineia a compreensão deste processo.

Eis que seguindo as lições de Carlos Roberto Martins Passos e Otto Nogami, (2003, p. 75), a demanda nada mais é do que a procura de um indivíduo por um determinado bem ou serviço. Neste ínterim pode-se identificar alguns elementos os quais compõe-se enquanto seus influenciadores, como o preço do bem, o preço dos bens relacionados, a renda do consumidor, bem como seu gosto e preferência. Estas elementares são as mais relevantes a serem consideradas quando do ímpeto de se perquirir a análise dos fatores determinantes para o condicionamento de uma demanda.

A oferta, por sua vez, ainda seguindo a lição de Passos e Nogami, (2003, p. 87), se traduz na quantidade de um determinado bem ou serviço que um produtor deseja vender no mercado. Eis que é influenciada por inúmeros fatores, dentre os quais sobressaem-se o preço do bem, o preço dos fatores de produção, a tecnologia, o preço de outros bens, e mesmo pelas condições climáticas na ocasião de se tratar de produtos agrícolas.

Muito embora se tratem de elementares provenientes da influência de fatores externos conforme disposto, a demanda e a oferta são fenômenos os quais são estudados levando-se em conta um cenário de equilíbrio estável do mercado, no qual as unidades econômicas não são capazes de influenciar de maneira isolada no preço uma vez que se pressupõe a existência de um elevado número de compradores e vendedores, tratando-se, conseguintemente, de uma análise teórica haja vista que só leva em conta o preço do bem, pressupondo-se a estabilidade dos demais fatores, ou seja, a observância da condição coeteris paribus, expressão latina que significa constante. Tal distinção se faz necessária a fim de que se persiga uma melhor apreensão dos fenômenos em estudo dado que a 
interveniência dos demais fatores nesta análise torná-la-ia desmesuradamente complexa, não alcançando os fins acadêmicos ao qual se compraz.

Eis assim que a representação teórica da demanda se perfaz da seguinte maneira:

\section{Gráfico 1: A demanda}

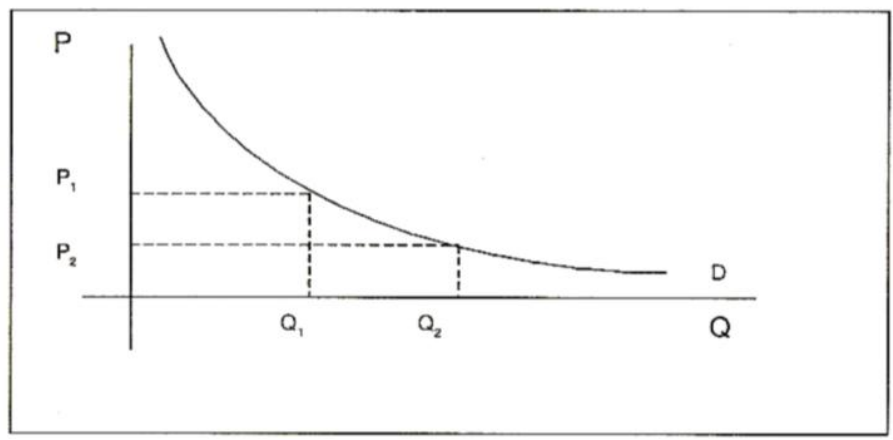

Fonte: BRUNA, Sergio Varella;2001. p.19.

Isto posto verifica-se a correlação entre o $P 1$ e $Q 1$ e $\mathrm{P} 2$ e Q2, de onde se faz notória a interrelação deflagrada entre preço e quantidade evidenciando-se enquanto grandezas inversamente proporcionais dado que o aumento no preço do produto induz a uma diminuição na quantidade demandada.

A oferta, por sua vez, conforma-se na seguinte representação:

Gráfico 2: A oferta

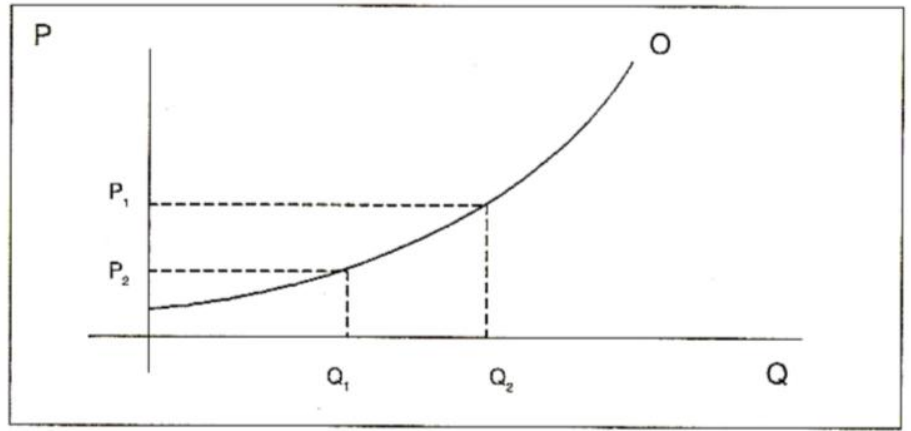

Fonte: BRUNA, Sergio Varella; 2001. p.19.

Desta visualização revela-se factível a relação diretamente proporcional estabelecida entre $P 1$ e $Q 1$ e $\mathrm{P} 2$ e $\mathrm{Q} 2$ onde à medida que o preço aumenta os produtores tornam-se dispostos a ofertar uma quantidade maior do bem, de maneira que o maior preço conferido ao bem induz a uma maior produção e disponibilização deste no mercado.

Da interposição dos gráficos da demanda e da oferta, no ponto de intersecção de ambas, verifica-se a situação de equilíbrio e o preço de mercado representado por E no gráfico 3, para o qual tenderão todas as operações no mercado, de modo que se o preço estiver acima 
do preço de equilíbrio observar-se-á um excesso de oferta desaguando numa competição entre os produtores para vender a mercadoria, havendo, então, uma pressão no sentido de o preço diminuir até atingir novamente o equilíbrio. Já se o preço estiver abaixo do preço de equilíbrio visualizar-se-á excesso de demanda, de maneira a suscitar uma competição entre os consumidores para adquirir a mercadoria dado que as quantidades demandadas serão maiores que as ofertadas, havendo, assim, uma pressão no sentido de o preço aumentar até atingir novamente o equilíbrio, conforme se verifica no gráfico que segue:

Gráfico 3: $\mathrm{O}$ equilíbrio

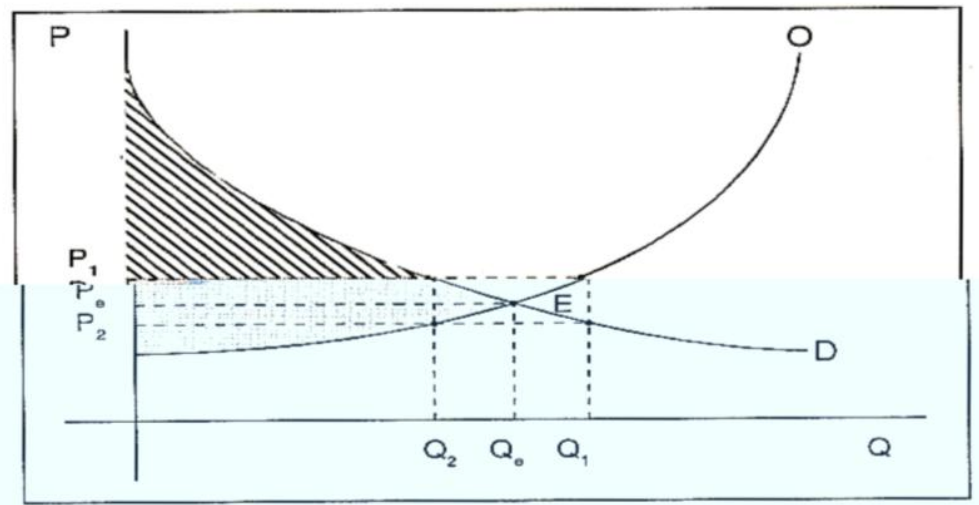

Fonte: BRUNA, Sergio Varella; 2001. p.23.

É a análise destes modelos que torna perceptível a função que os preços exercem na economia haja vista que se verificando uma elevação da demanda por um determinado bem em um dado mercado este aumento será indutor da elevação dos preços desse bem, induzindo ao interesse de novos produtores dispostos a adentrar tal mercado influenciados pelos ganhos que a maior procura pelo bem pouco disponibilizado suscitou. Por outro lado, verificando-se a efetiva entrada destes novos produtores no mercado, o incremento dos produtos por eles disponibilizados minimizará a escassez, bem como os preços, sendo este aumento na concorrência decisivamente benéfico para os consumidores posto que acirra a competição entre os produtores induzindo à preços menores havendo consequiente minimização dos lucros do ofertante.

Muito embora o preço seja fator decisivo para a continuidade da produção de um dado bem por certo produtor, bem como para a compra de um determinado bem por certo consumidor, a variação do preço não é sempre indicativa de uma variação na sua oferta ou procura, havendo, pois, a necessidade de se levantar a elasticidade da procura e a elasticidade da oferta.

A elasticidade, que no dizer de Sérgio Varella Bruna (2001, p. 20), é "a proporção relativa em que variam os preços à medida que ocorrem variações na oferta ou na procura", são situações nas quais o aumento do preço de um certo produto não faz a demanda cair, tampouco um maior custo de produção remete a uma diminuição da produção por parte do produtor. Nestas ocasiões os bens em enfoque gozam de grande elasticidade de maneira que embora haja aumento sensível no seu preço ainda assim os compradores permanecem a adquiri-los, bem como havendo considerável diminuição do seu preço para venda, os produtores permanecem dispostos a ofertá-los. Nestas situações, embora se deflagre 
notória variação no preço do bem, adquiri-lo ou ofertá-lo continua sendo uma alternativa viável para os agentes econômicos.

Eis que inda à espreita das lições do referido autor, as elasticidades, por expressarem razões existentes entre duas variáveis, são representadas simbolicamente pela letra $e$, sendo a demanda elástica quando a variação nela verificada for superior à variação proporcional dos preços $(e>1)$; inelástica, caso tal variação seja inferior à variação proporcional dos preços $(e<1)$; e de elasticidade unitária, caso as variações ocorridas no preço e nas quantidades procuradas se dêem exatamente na mesma proporção $(e=1)$.

Gráfico 4: Elasticidade da demanda

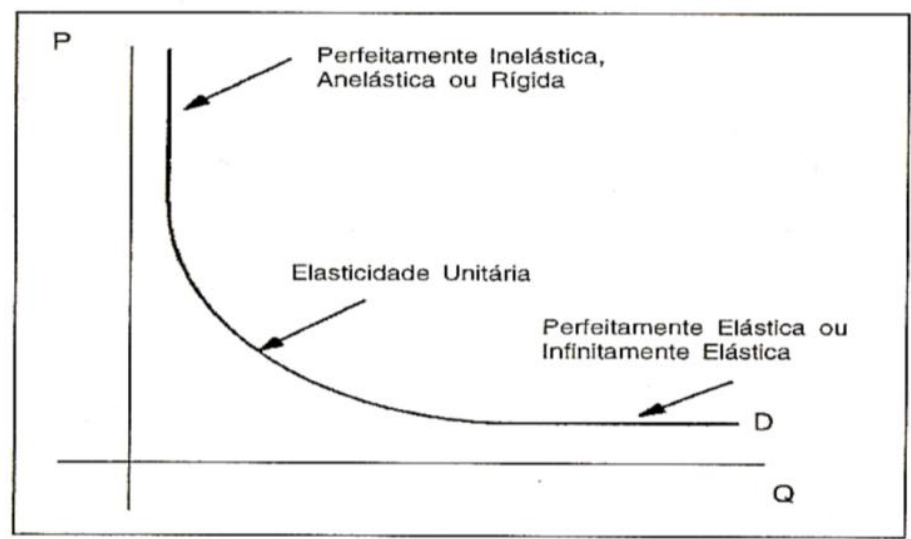

Fonte: BRUNA, Sergio Varella; 2001. p.21.

No caso da oferta a elasticidade será unitária caso a variação dos preços ocorra na mesma proporção da variação das quantidades ofertadas $(e=1)$; será elástica se a quantidade ofertada variar em proporção maior do que a variação dos preços $(e>1)$; e inelástica se a variação for proporcionalmente menor do que a ocorrida nos preços $(e<1)$.

Gráfico 5: Elasticidade da oferta

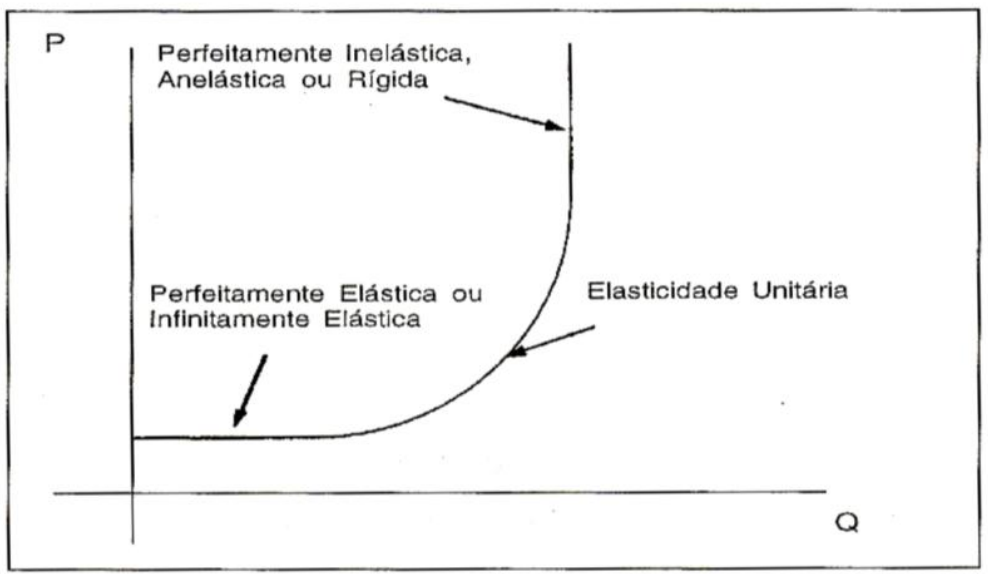

Fonte: BRUNA, Sergio Varella; 2001. p.22. 
Á análise da tutela jurídica da concorrência, o prévio estudo das elasticidades da procura e da oferta se denotam primordiais visto que estas deflagram a relação entre produtores e consumidores no que atine à situação de equilíbrio ou de preponderância entre eles, podendo até mesmo ser suficiente para deflagrar situações de abuso do poder econômico, quando, exemplificativamente, no caso da elasticidade da oferta se verificar uma procura inelástica, na qual o produtor pratique preços muito superiores ao que seria comum no mercado, ainda assim não tendo perda sensível nas vendas, de maneira a auferir lucros superiores aos que se verificariam em condições de equilíbrio.

$\mathrm{Na}$ persecução da análise da tutela da concorrência, a fim de que se compreenda o fenômeno da manifestação abusiva de poder econômico, faz-se elementar ainda a prévia intelecção do que seja um cenário de equilíbrio a fim de que a não observância deste equilíbrio desnude esta manifestação. Assim, memorável é a análise do modelo da concorrência perfeita posto que seja uma construção teórica ideal, dado que não contempla as distorções inerentes aos mercados reais, porém, serve de parâmetro para a compreensão destas estruturas reais mais complexas.

O modelo da concorrência perfeita se alicerça sobre os pressupostos de que há no mercado um grande número de compradores e vendedores de maneira que a atuação isolada de qualquer um deles é incapaz de influenciar no preço dos bens, ou seja, a participação de cada um deles na oferta ou na procura global é tão insignificante que é incapaz de afetar sensivelmente os volumes oferecidos ou procurados sendo, portanto, incapaz de modificar o preço de equilíbrio. Além disso, pressupõe-se nessa estrutura a homogeneidade dos produtos, que no dizer de Passos e Nogami, "são perfeitos substitutos entre si", de maneira que "os compradores são indiferentes quanto à firma da qual eles irão adquirir o produto". (2003, p. 288).

Nesta estrutura também se pressupõe que inexistam barreiras legais e/ou econômicas para a entrada e a saída de empresas no mercado, bem como a total transparência das informações mercadológicas tal qual aduz Passos e Nogami:

“(...) tanto compradores quanto vendedores têm informação perfeita sobre o mercado: ambos conhecem a qualidade do produto e seu preço vigente. Os vendedores conhecem também os custos e lucros de seus concorrentes. Assim é que, pelo fato de inexistir desinformação, nenhum comprador estará disposto a adquirir um produto por um preço superior ao vigente; pelo mesmo motivo, nenhum vendedor estará disposto a vender seu produto por um preço inferior ao de mercado". (2003, p. 289)

Nesta conjuntura a situação de equilíbrio disposta no gráfico 3 irá naturalmente se instalar. Apesar disso, analisando-se um produtor individual sua curva de procura terá um perfil diferenciado ao do gráfico 3. Tal qual suscita Sérgio Varela Bruna, "como sua participação na quantidade ofertada é insignificante, a curva será horizontal, não decrescente, tendendo ao infinito". (2001, p. 27).

Ainda em alusão ao mestre, individualmente considerado o comportamento do competidor não é diferente o do monopolista:

“(...) tal como este procura aquele maximizar seus lucros. A diferença, entretanto, reside no fato de que o competidor não é capaz de influir de 
forma sensível no volume total da quantidade ofertada no mercado e, portanto, sobre os preços nele vigentes”. (2001, p. 29).

Nesta análise a situação de monopólio se deflagra quando da existência de um único produtor de um determinado bem o qual não detém substituto próximo, residindo aí a capacidade de influenciar no preço posto que se verifica um único agente hábil a ofertar determinado bem no mercado.

Os pressupostos, por conseguinte, que condicionam a estrutura de monopólio são, tal qual disposto, a existência de uma única empresa ofertando um determinado produto em um mercado no qual não há bons substitutos e existem obstáculos à entrada de novos ofertantes no mercado, ou seja, barreiras que impedem ou dificultam excessivamente a entrada de novos concorrentes, matéria esta que será analisada mais adiante em pormenor. Em suma, em uma situação de monopólio, conforme ilustra Sérgio Varela Bruna:

“(...) a sociedade é submetida a uma escassez artificial, provocada pelo monopolista, que controla totalmente a oferta, a fim de maximizar seus lucros. Esta parcela excedente de lucros é retirada da comunidade por força da manifestação do fenômeno do poder econômico e representa, além de ineficiência econômica, injustiça social, no que se refere à repartição da renda". (2001, p. 34).

A estrutura mercadológica da concorrência monopolista por sua vez, pressupõe a congruência de "elementos da concorrência perfeita e do monopólio, ficando em situação intermediária entre essas duas formas de organização de mercado", conforme dicção de Passos e Nogami. (2003, p. 346). Eis que as hipóteses básicas que corroboram esta estrutura são a existência de um grande número de compradores e vendedores, a diferenciação do produto, vez que não serão homogêneos, mas sim deterão especificidades conforme seja o grau de diferenciação buscado pelo produtor para garantir ao seu produto a fim de torná-lo único, bem como a existência de livre entrada e saída de empresas no âmbito do mercado dada a inobservância de barreiras obstativas.

Nessa estrutura, a diferenciação dos produtos é que garante ao produtor uma conduta monopolista, de maneira que cada produtor possui alguma liberdade para fixar seus preços, residindo aí sua capacidade de determiná-los inexoravelmente frente ao mercado.

Já na estrutura oligopolista observa-se a atuação de um pequeno número de empresas controlando a oferta de um determinado bem. A aferição deste número dependerá da natureza da indústria devendo ser pequeno, "de tal forma que as firmas levam em consideração e reagem às decisões quanto a preço e produção de outras", conforme aduz Passos e Nogami.(2003, p. 351). Além disso, o oligopólio poderá ser puro ou diferenciado. Quando puro, os concorrentes oferecem um produto homogêneo, ou seja, substitutos perfeitos entre si. Quando diferenciado, verificar-se-á a oferta de produtos heterogêneos. Nesta estrutura também se identifica a existência de barreiras impeditivas à entrada de novas concorrentes.

Embora se trate factualmente de uma estrutura consolidada, a doutrina econômica acerca dos oligopólios ainda é incipiente e controversa, uma vez que são inúmeras as maneiras 
pelas quais um oligopolista pode agir e reagir. Assim sendo, três são as situações suscitadas por Passos e Nogami como sendo caracterizadoras da atuação oligopolista: a liderança de preços, conquanto seja uma forma de conluio imperfeito em que as empresas do setor oligopolista decidem, sem acordo formal, estabelecer o mesmo preço, aceitando a liderança de preço de uma empresa da indústria. Nesse modelo pressupõe-se que a liderança decorre do fato de uma das empresas rivais possuir estrutura de custos mais baixos que as demais. Por essa razão, consegue se impor como líder do grupo.

De início, os preços podem ser diferenciados, o mercado, entretanto, preferirá o produto que esteja sendo ofertado a preços mais baixos, restando duas possibilidades às empresas: manter seu preço, e como conseqüência serem alijadas do mercado, ou aceitarem o preço praticado pela rival de menores custos, que é mais baixo, e permanecerem no mercado, porém sem maximizar seus lucros.

Assim é que a empresa líder de preços fica, por meio de um acordo tácito responsável pela determinação do nível de preço do produto, e as menos favorecidas em termos de preços tornam-se seguidoras dos preços fixados pela líder.

Outra característica observada é a competição extra-preço, a qual refere-se à propaganda, promoção de vendas, serviços ao cliente e toda e qualquer ação desenvolvida no ímpeto de diferenciação do produto. Uma empresa oligopolista se empenha nessas atividades a fim de convencer os clientes de que seu produto é superior ao de suas rivais, e sendo bem sucedidos, estes mecanismos de diferenciação do produto podem permitir à empresa oligopolista captar uma parte maior do mercado.

Por fim, tem-se o cartel como a terceira e última das características relacionadas à atuação oligopolista. Trata-se de uma organização formal de produtores dentro de um setor. Essa organização formal determina as políticas e decisões para todas as empresas-membro. Assim, por meio de uma agência coordenadora, organizam-se as empresas de forma que elas ajem como se participassem de um grande conglomerado monopolista, possuidor de várias fábricas. Por essa razão tal forma de conluio perfeita leva à solução do monopólio.

Nesta composição muitas vezes os acordos entre firmas concorrentes são tornados públicos, em outras, a prática da cartelização ocorre sem que haja qualquer documento; existe, ainda, a concretização do cartel de forma disfarçada por intermédio dos sindicatos, associações e clubes.

Na realidade, tal qual asseveram Passos e Nogami, é válido ressaltar que os cartéis são instáveis:

\footnotetext{
"'porque cada firma tem um incentivo para quebrar seu acordo, caso acredite que suas ações não serão percebidas pelas outras firmas. Uma firma pode ser tentada a baixar seu preço por uma pequena quantia, procurando, dessa forma, ganhar uma parte do mercado. Essa firma aumentará seus lucros, contanto que seu preço mais baixo exceda o custo marginal e seus rivais ignorem suas ações. Entretanto, quando essa firma for descoberta pelas outras firmas, elas irão baixar seus preços, retaliando a firma que descumpriu o acordo, dando início a uma guerra de preços que culminará com o fim do cartel. Os cartéis geralmente têm vida curta em virtude de tal comportamento". (2003, p. 352).
} 
Os cartéis que normalmente obtêm êxito são aqueles que têm uma firma dominante (ou país) que age punindo as firmas que transgridem os acordos existentes. Um exemplo de cartel de sucesso é a Organização dos Países Exportadores de Petróleo - a OPEP.

Eis que a estruturação dos mercados na conformação de estruturas monopolistas e oligopolistas são máximas factuais posto que as imperfeições neles observáveis são oriundas das diferenças entre os agentes econômicos no que tange aos recursos disponíveis pelos mesmos. Estas diferenças é que dão o tom à cíclica mercadológica, suscitando uma maior ou menor capacidade de influenciar nos preços, o que se traduz numa elementar estruturadora da conjuntura econômica que, no entanto, deve encontrar limitações diante das diretrizes normativas estruturadoras da ordem econômica nacional dos países haja vista que são elas que vão balizar o comportamento dos agentes dentro da esfera do que seja permitido ou proibido, ensejando a persecução dos comportamentos que se afiguram dentro da esfera do que seja tido como legal ou ilegal, adentrando aí a necessidade de atuação dos operadores do Direito a fim de que se coíbam as práticas concorrências atentatórias à salutar conformação da ordem econômica nacional, sendo, pois, o alvo da análise que se segue.

\section{A LIVRE CONCORRÊNCIA E O PODER NA ECONOMIA DE MERCADO}

A troca é o fato econômico basilar, estruturador da ordem econômica. Eis assim que detém uma dimensão social, sendo regulamentada pelo Direito por meio do estabelecimento de um regime de obrigações que se cumprem coativamente quando o comportamento espontâneo das partes envolvidas deixa de atender às vontades mútuas.

Eis que a economia de mercado, tal qual observado por Washington Peluso Albino de Souza, (2005, p. 238), é baseada no fato econômico da troca, aperfeiçoada por instrumentos como a moeda e o crédito, alicerçada sob o princípio da disputa, da luta pela vida, que diuturnamente norteou o pensamento filosófico e político do século XIX.

Assim a atividade econômica se imbuiu de tal ideologia pela disputa concretizada pela concorrência no mercado. Cada concorrente exercia livremente o seu poder econômico privado, sendo o Estado coadjuvante neste cenário posto que só intervinha quando chamado judicialmente para restabelecer o respeito aos dispositivos livremente convencionados nos próprios contratos estabelecidos entre as partes, os quais figuravam como instrumentos fundamentais na objetivação do próprio Direito e eram a expressão máxima dos interesses das partes consubstanciados pela "autonomia da vontade", prerrogativa esta inerente ao relacionamento entre os indivíduos.

A lei da "Oferta e Procura" na qual a economia seria orientada unicamente pela livre atuação dos ofertantes e compradores, adquiria neste ínterim cada vez mais força. A atuação indiscriminada dos agentes econômicos é que dava o tom à economia, tendo a satisfação das necessidades individuais enquanto elementar norteadora da cíclica econômica, de forma que as condições individuais da procura e as técnicas da oferta ditariam naturalmente a quantidade de bens aptos à transação e adequados à determinada satisfação, sendo, pois, antagonista a atuação estatal.

A leniência do Estado perante tal cenário, no entanto, deu ensejo à insurgência precoce de manifestações concorrenciais distorcidas calcadas pelo predomínio dos agentes econômicos mais fortes sobre os mais fracos, ou seja, daqueles detentores de superior 
poder econômico sobre os inferiores. Tais distorções se debelaram mediante a insurgência de mecanismos tendentes à dominação de mercados como monopólios e oligopólios, verificando-se, assim, a superveniência da "lei econômica da concentração", que, tal qual preleciona Washington Peluso: "agora, pelo fato econômico da concentração, o sujeito concorrente encontrou-se diante da fatalidade de crescer ou perecer, ou seja, de aumentar sucessivamente sua capacidade de luta, e, portanto, o seu poder econômico; ou de ser lançado fora da arena e derrotado". (2005, p.240).

$\mathrm{Na}$ moderna economia de mercado estes mecanismos ganham a proporção de fatos econômicos e comandam a dinâmica econômica, de maneira que a concentração passa de natural a provocada, sendo inclusive amparada por instrumentos jurídicos disciplinadores tal qual previsto na Lei $n^{\circ} 6.404 / 76$, a lei brasileira das sociedades anônimas, que prevê no artigo 118 a operação de Fusão, ato pela qual duas ou mais empresas se extinguem para originar uma nova empresa que deterá os ativos e passivos das empresas fundidas; a Incorporação, que conforme disposto no artigo 227 é a operação pela qual uma ou mais sociedades são absorvidas por outra, que lhe sucederá nos direitos e obrigações.

A Cisão, que de acordo com o artigo 229 da supramencionada lei é a operação pela qual a companhia transfere parcelas do seu Patrimônio para uma ou mais sociedades constituídas para esse fim ou já existentes, extinguindo-se a sociedade cindida, se houver versão total do seu patrimônio, ou dividindo-se o seu Capital, se parcial a versão; e ainda os Consórcios de empresas e Grupos de sociedades que também são referenciadas na disciplina legal da Lei das sociedades anônimas, sendo os consórcios a união de sociedades em proveito de um determinado empreendimento, sem a perda da personalidade jurídica das envolvidas e sem abdicar de sua autonomia administrativa, muitas vezes nem detendo participação societária; e os grupos de sociedades são aquelas conformações nas quais empresas poderão formar grupos mediante a instituição de uma convenção pela qual as participantes se obrigam a combinar recursos e ou esforços comuns.

Acordos e ajustes autônomos firmados entre empresas também se configuram enquanto mecanismos de concentração dado que remetem aos mesmos fins econômicos de dominação: a determinação de preços e o controle de mercado.

Os conglomerados, resultantes da união de empresas atuantes em diferentes ramos entre si que carreiam resultados das transações de seus diferentes segmentos em benefício das componentes desta união, também se presentificam enquanto expressão dessa dinâmica de concentração calcada no ímpeto de dominação de mercados. A pujança das holdings, instituídas no ímpeto de administrar, estruturar e coordenar a estabilidade destes conglomerados também são uma irrefutável evidência do processo de concentração pelo qual as empresas vem remetendo os mercados, que transcende mesmo os limites territoriais locais dada a dimensão que adquirem, encampando uma dimensão global onde o mundo se torna um mercado unificado, vez que, conforme aduz Peluso:

“em lugar das 'empresas nacionais' e 'empresas estrangeiras' em relação a cada país, surgiram as empresas multinacionais, por sua vez, geralmente componentes de grandes conglomerados e que atuam nas economias internas, como nacionais em cada país, porém obedecendo a orientação acima dos mesmos, além de apresentarem dimensões capazes de lhes impor o seu Poder, de modo irretorquível. (2005, p. 241). 
A limitação a este poder, no entanto, no âmbito nacional, em Direito Positivo, ou seja, codificado, encontra-se determinado no texto constitucional pelos princípios ideológicos que constituem o seu regime jurídico, delineando o que se convenciona como permitido ou proibido, bem como sua forma de repressão e sanção. Conforme aduz Peluso o Poder Econômico Público estabelece as condições do "lícito" e do "ilícito", do "justo" e do "injusto", e no que atine à concorrência surgem as hipótese legais do "uso" e do "abuso" do poder econômico. "Em todas estas hipóteses, a atividade econômica se manifesta sob as mais diversas formas e os mais variados expedientes que a Ciência Econômica apresenta e aperfeiçoa, e que nem sempre recebem o beneplácito do Direito”. (2005, p. 243).

Eis que à disciplina jurídica da tutela da concorrência cabe a análise dos dispositivos constitucionais nacionais para fins da configuração da conduta dentro do plexo de licitude ou não que a própria Carta Magna acaba por deflagrar, vez que ela subsidia as diretrizes econômicas em adoção na sistemática econômica nacional, de maneira que as concretas manifestações de poder econômico e exercício abusivo do poder econômico devem ter a escorreita apreciação mediante a confluência de seus aspectos factuais de manifestação e as diretrizes encampadas pelo arcabouço normativo nacional as quais detém objetivo reflexo frente às diretrizes suscitadas constitucionalmente que são basilares na delimitação destas condutas.

\section{OS PRINCÍPIOS DA LIVRE INICIATIVA E DA LIVRE CONCORRÊNCIA NO ÂMBITO DA CONSTITUIÇÃO BRASILEIRA DE 1988}

O Direito Constitucional, conforme seja a gênese dos demais ramos do Direito, enfeixa todos os princípios jurídicos, indispensáveis à organização do próprio Estado, à constituição de seu governo, dos poderes públicos, à declaração de direitos das pessoas, quer físicas, quer jurídicas, "traçando assim os limites de ação do Estado, na defesa de seus precípuos objetivos e na defesa dos interesses da coletividade que o compõe" tal qual aduz Silva, (2002, p. 270). Eis que assim os princípios constitucionais consubstanciam o arcabouço existencial de um Estado, perpassando todos os âmbitos institucionais, sendo, portanto, basilar à sua própria organização enquanto entidade política e soberana.

Assim sendo, ainda conforme Silva, os princípios são as normas elementares que revelam o conjunto de regras ou preceitos que se fixam para servir de sustentação a toda espécie de ação jurídica, traçando assim a conduta a ser observada. Deste modo exprimem sentido mais relevante que o da própria norma ou regra jurídica. Denotam-se na própria "razão fundamental de ser das coisas jurídicas, convertendo-se em perfeitos axiomas. Sem dúvida, significam os pontos básicos, que servem de ponto de partida ou de elementos vitais do próprio Direito”. (2002, p. 639).

Eis que assim, na vigente Constituição brasileira, promulgada em 5 de outubro de 1988 a qual instituiu a República Federativa do Brasil enquanto Estado Democrático de Direito pautado nos princípios fundamentais da soberania, da cidadania, da dignidade da pessoa humana, dos valores sociais do trabalho e da livre iniciativa e do pluralismo político, conforme artigo $1^{\circ}$ da Constituição, instituitu por conseguinte estes princípios como sendo diretrizes basilares norteadoras de todo arcabolço normativo nacional. Neste ponto, a fundamentação da ordem econômica constitucional alicerçada sobre as bases da valorização do trabalho humano e da livre iniciativa, tal qual disposto reiteradamente no 
artigo 170, se traduz na ratificação da ordem principiológica basilar da Contituição brasileira, e no dizer do ilustre Tércio Sampaio Ferraz Júnior ${ }^{1}$, em comento na lição de Eros Roberto Grau:

"O art. 170, ao proclamar a livre iniciativa e a valorização do trabalho humano como fundamentos da ordem econômica, está nelas reconhecendo a sua base, aquilo sobre o que ela se constrói, ao mesmo tempo sua conditio per quam e conditio sine qua non, os fatores sem os quais a ordem reconhecida deixa de sê-lo, passa a ser outra, diferente, constitucionalmente inaceitável (...). Afirmar a livre iniciativa como base é reconhecer na liberdade um dos fatores estruturais da ordem, é afirmar a autonomia empreendedora do homem na conformação da atividade econômica, aceitando a sua intrínseca contingência e fragilidade; é preferir, assim, uma ordem aberta ao fracasso a uma 'estabilidade' supostamente certa e eficiente. Afirma-se, pois, que a estrutura da ordem está centrada na atividade das pessoas e dos grupos e não na atividade do Estado. Isto não significa, porém, uma ordem do 'laissez faire', posto que a livre iniciativa se conjuga com a valorização do trabalho humano, mas a liberdade, como fundamento, pertence a ambos". (1988,p. 232).

Assim que da observância dos princípios constitucionais que norteiam a ordem econômica arrolados no artigo 170 da Constituição, tem-se a livre concorrência enquanto desdobramento do princípio da livre iniciativa, posto que estes princípios se complementam e se voltam à preservação do modo de produção capitalista uma vez que o princípio da livre concorrência, compreendido na liberdade de concorrer, de competir, subsume-se na liberdade de iniciativa inerente a todo ser, liberdade esta concretizável na expressão da própria criatividade, na participação da construção da riqueza econômica de maneira a se assegurar a todos condições de intervenção no seio econômico no ímpeto da persecução da existência digna, conforme os ditames da justiça social.

Assim o é que, ainda segundo Tércio Sampaio, a livre concorrência trata-se, modernamente, de um processo comportamental competitivo, sendo a competitividade o elemento que define a livre concorrência. A competitividade exige, portanto, a descentralização da coordenação como base da formação dos preços, o que supõe livre iniciativa e apropriação privada dos bens de produção.

Neste sentido, a livre concorrência é forma de tutela do consumidor, na medida em que competitividade induz a uma distribuição de recursos a mais baixo preço. De um ponto de vista político, a livre concorrência é garantia de oportunidades iguais a todos os agentes, ou seja, é uma forma de desconcentração de poder. Por fim, de um ângulo social, a competitividade deve gerar extratos intermediários entre grandes e pequenos agentes econômicos, como garantia de uma sociedade mais equilibrada.

Ainda neste tocante, José Afonso da Silva aduz que os dois dispositivos - a livre iniciativa e a livre concorrência, se complementam no mesmo objetivo. "Visam tutelar o sistema de mercado e, especialmente, proteger a livre concorrência contra a tendência açambarcadora da concentração capitalista". Assim, a "Constituição reconhece a existência do poder econômico. Este não é, pois, condenado pelo regime constitucional. Não raro esse poder econômico é exercido de maneira anti-social". (1998, p. 760).

\footnotetext{
${ }^{1}$ A economia e o controle do Estado. Parecer publicado no jornal O Estado de S. Paulo, p. 50, em 04.06.1989, em alusão na obra de Eros Roberto Grau.
} 
$\mathrm{Na}$ acurada lição de Eros Roberto Grau o constitucionalista encerra criticamente a análise do princípio constitucional da livre concorrência dispondo que:

\begin{abstract}
"A livre concorrência, no sentido que lhe é atribuído - 'livre jogo das forças de mercado, na disputa de clientela' -, supõe desigualdade ao final da competição, a partir, porém, de um quadro de igualdade jurídicoformal. (...) Não há oposição entre o princípio da livre concorrência e aquele que se oculta sob a norma do $\S 4^{\circ}$ do art. 173 do texto constitucional, (...) que se expressa como princípio da repressão aos abusos do poder econômico e, em verdade - porque dele é fragmento compõe-se no primeiro. É que o poder econômico é a regra e não a exceção. Frustra-se, assim, a suposição de que o mercado esteja organizado, naturalmente, em função do consumidor. A ordem privada, que o conforma, é determinada por manifestações que se imaginava fossem patológicas, convertidas, porém, na dinâmica de sua realidade, em um elemento próprio a sua constituição natural”. (1988, p. 234).
\end{abstract}

Nesse ínterim, a livre concorrência se traduz salutar no âmbito de uma economia de mercado uma vez que reside nela a liberdade de atuação, fundamental para o desenvolvimento democrático da estrutura econômica. Concorrer significa competir, e é nessa competição que se busca o aprimoramento para se galgar posições no mercado, não destoando, no entanto, da elucidação de objetivos lícitos, compatíveis com as disposições legais do ordenamento jurídico nacional, posto que da análise crítica supra, depreende-se que a lei tutela a livre concorrência, esta que se concretiza na observância fática da livre força competitiva dos agentes econômicos no âmago do mercado, manifestada pelo poder econômico exercido por cada um destes agentes conforme seja seu aparato de recursos disponíveis, no entanto, no artigo $173 \S 4^{\circ}$ da Constituição, resta ressalvada a garantia de que "a lei reprimirá o abuso do poder econômico que vise à dominação dos mercados, à eliminação da concorrência e ao aumento arbitrário dos lucros", ou seja, repressão não ao poder econômico mas à sua manifestação abusiva.

Neste ponto, Celso Antonio Bandeira de Melo, (2008, p. 785), ressalta que a Administração Pública não tem título jurídico para aspirar a reter em suas mãos o poder de outorgar aos particulares o direito ao desempenho de qualquer atividade econômica, também lhe falecendo o poder de fixar o montante da produção e comercialização que os empresários por ventura intentem efetuar, isto porque "de acordo com os termos constitucionais, a eleição da atividade que será empreendida assim como o quanto a ser produzido ou comercializado resultam de uma decisão livre dos agentes econômicos". O direito de fazê-los lhes advém diretamente do texto constitucional e descende da própria acolhida do regime capitalista. Assim posto, ao Estado cabe dirimir, mediante lei, não a livre manifestação do poder econômico, mas os possíveis abusos visualizáveis em seu exercício.

Nas letras no artigo 174 tem-se que "como agente normativo e regulador da atividade econômica, o Estado exercerá, na forma da lei as funções de fiscalização, incentivo e planejamento, sendo este determinante para o setor público e indicativo para o setor privado". Assim, o Estado não pode impor aos particulares o atendimento às diretrizes ou mesmo a intenções pretendidas, mas tão somente incentivar e atrair os particulares 
mediante planejamento indicativo que se apresente favorável para o condicionamento da atuação da iniciativa privada.

O parágrafo único do já supracitado artigo 170 embora reafirme tal competência estatal, opõe-lhe exceções dado que, segundo seus termos: "é assegurado a todos o livre exercício de qualquer atividade econômica, independentemente de autorização de órgãos públicos, salvo nos casos previstos em lei.

Vale dizer: o parágrafo único não conferiu à lei o poder de excepcionar, a quem quer, seja o exercício livre - e em livre concorrência - de qualquer atividade econômica. O que foi permitido é que a lei excepcionasse o direito de exercê-la independentemente de algum ato de autorização de órgãos públicos. Em suma, aduz Celso Antonio Bandeira de Melo:

"O que a lei pode ressalvar é a desnecessidade de autorização para o exercício de certas atividades; nunca, porém, restringir a liberdade de empreendê-la e na medida desejada. E, por isto mesmo (...) dita autorização 'ou denegação' evidentemente, não concerne aos aspectos econômicos, à livre decisão de atuar nos setores tais ou quais e na amplitude acaso pretendida, mas ao ajuste do empreendimento a exigências atinentes à salubridade, à segurança, à higiene do meioambiente, à qualidade mínima do produto em defesa do consumidor". (2008, p. 787).

Ressalte-se que tais autorizações não dizem respeito aos aspectos econômicos, pois neste tocante os agentes são livres, haja vista que tem assegurado pela Constituição seus direitos à liberdade de iniciativa, à liberdade de concorrência e à garantia de que o planejamento econômico que o poder público faça apresentar-se-lhes-à com caráter meramente indicativo, não podendo implicar sujeição ou cerceio algum à liberdade econômica que lhes é reconhecida pela lei Magna.

Neste tocante o parágrafo único institui ser assegurado a todos o livre exercício de qualquer atividade econômica de maneira que o Estado não pode restringir o exercício de tal atividade, pois seja esta qual for ela é insuscetível de ser excluída do âmbito de ação dos particulares, sendo exceção ao dispositivo apenas as atividades econômicas que a própria Constituição, no artigo 177, institui enquanto monopólio estatal.

Desta feita, a livre atuação no mercado se traduz em prerrogativa inerente a todos os membros do corpo social, posto que seja direito constitucionalmente garantido independentemente da oitiva da administração pública, muito embora existam atividades econômicas que a administração, por lei, tem sido habilitada a autorizar o seu exercício, dentre as quais "empreendimentos cuja índole propiciem agravos ecológicos, ou produtos tais como agrotóxicos, medicamentos e alimentos industrializados" que a lei subordina seu ingresso no mercado a demonstrações prévias da lisura quanto ao oferecimento de riscos à saúde, não havendo, portanto, mitigação à livre atuação, mas tão somente prévia averiguação, tal qual dicção do renomado Bandeira de Mello. (2008, p. 788).

Assim, a livre concorrência se encerra na liberdade de atuação dos agentes econômicos mediante o estabelecimento de parâmetros preteritamente definidos pela administração pública, dada a elucidação de políticas econômicas indicativas da atuação privada no seio 
econômico, proporcionando ainda a liberdade de escolha dos consumidores, de maneira que a competitividade entre os agentes na busca por "fatias de mercado" gradativamente maiores passa a ser a tônica da economia, ensejando, por conseguinte, a busca pelo aperfeiçoamento, pelo desenvolvimento das melhores práticas, das mais modernas técnicas, dos mais criativos e econômicos processos e procedimentos produtivos, dando o tom à cíclica dos mercados de produção, comercialização e consumo, propiciando a infinda circulação da riqueza.

Pelo exposto, o que se protege pela livre iniciativa e, conseqüentemente, pela livre concorrência, é a liberdade de trabalho, a liberdade de ação e criação; a liberdade de todas as formas de produção, individual ou coletivamente, garantidoras da possibilidade de participação na produção da riqueza, persecutoras, por conseguinte, de uma existência humana digna.

\section{A CARACTERIZAÇÃO DO PODER ECONÔMICO}

Conforme seja a livre concorrência a tônica dos mercados, tal elementar norteia a participação indiscriminada dos agentes econômicos no seio social, assim sendo, tal princípio se externaliza pela produção e comercialização de produtos e serviços aos mais variáveis quanto à natureza humana possa demandar e seus agentes estejam aptos a desenvolver e tornar comercializável, para tal, criando políticas e desenvolvendo mecanismos de mercado capazes de fazer emergir estruturas que fomentem a participação e a consolidação destes produtos e serviços frente às efemérides de uma economia sinuosa e ferrenhamente concorrencial.

Tal elementar se perfaz uma vez que a concorrência entre as empresas não se limita aos concorrentes vislumbráveis nos limites territoriais nos quais estas encontram-se instaladas. A concorrência cada vez mais exaure as fronteiras dadas às facilidades que o mundo globalizado oferta à circulação de produtos e serviços, e é esta disponibilidade que torna o mundo um mercado unificado, onde as empresas de um mesmo segmento, direta ou indiretamente, se concretizam enquanto concorrentes, porém, alguns ramos com maior profusão e outros nem tanto.

Esta visualização do grau de concorrência entre empresas atuantes em um mesmo segmento se faz perceptível mediante a análise do poder econômico a elas inerente. A fim de que tal mensuração seja possível, primordial faz-se o prévio exame do que seja a noção de mercado relevante.

\section{O MERCADO RELEVANTE}

Das lições de Sérgio Varella Bruna, denota-se mercado como sendo um sistema, um espaço econômico no qual se realizam as relações de troca de toda sociedade e onde são ofertadas e procuradas as mais diversas espécies de produtos. Tais produtos, no entanto, não concorrem diretamente entre si, assim será apenas quando se observar a existência de grande diferenciação, de forma que não há um só mercado, "senão uma rede de mercados, em estreita relação, um para cada vendedor”. (2001, p. 77). 
Tal qual dispõe o mestre, o produtor de coca-cola, por exemplo, embora seja o único a produzir essa variedade de produto, enfrentará, apesar da especificidade, a concorrência de outros refrigerantes. Ademais, ainda que haja o monopólio de um determinado bem, que detenha um grau de diferenciação tal que confira ao produtor grande influência sobre o preço de mercado, tal poder ainda não será absoluto uma vez que o monopolista enfrentará ainda a concorrência dos bens sucedâneos, ou seja, substitutos, que podem ser consumidos em substituição a outro.

Eis que para a aferição do poder econômico denota-se imprescindível a análise dos produtos que concorrem entre si, compondo um mercado apartado dos demais, ou seja, o mercado a ser considerado relevante para fins de averiguação da tutela da concorrência e, por conseguinte, do poder econômico inerente.

Neste sentido Varella Bruna ressalta que o conceito de mercado relevante teve origem no Direito norte-americano diante do caso United States versus E. I. Du Pont de Nemours \& Co no ano de 1956. Na ocasião a Du Pont, empresa produtora de papel celofane, fora acusada pelo governo americano de monopolizar o mercado de celofane, infringindo a secção segunda do Sherman Act, lei federal americana de defesa da concorrência, que prevê disposições proibindo atuações concorrenciais de mercado que restringem o comércio, sendo a secção segunda tocante à monopolização ou tentativa de monopolização de mercados. Á época, a empresa, durante o período abrangido pelo processo, fora responsável por $75 \%$ de todo papel celofane produzido nos Estados Unidos, sendo sua principal concorrente limitada a $20 \%$ das vendas em razão de um acordo de licença de patente mantido com a própria $\mathrm{Du}$ Pont no qual foram estabelecidos royalties progressivos de acordo com a escala de produção, o que consequentemente limitava o aumento da participação da concorrente.

A empresa defendeu-se alegando que enfrentava a concorrência de outros materiais de embalagem, como o papel alumínio e outros derivados do plástico, de maneira que o mercado a se considerar era o de materiais flexíveis para embalagens, onde o celofane detinha menos de $20 \%$ do consumo total nos Estados Unidos. A alta corte americana, acolhendo tal entendimento absolveu a empresa da acusação de tentativa de monopólio.

Assim a noção de mercado relevante, decorrente da literal tradução da palavra - relevant, expressa mais do que a noção de importante, denota algo como mercado relativo, ou mercado pertinente, "no qual os produtos dele inerente são, em conjunto, objeto da concentração de ofertas e procuras que caracterizam a própria noção econômica de mercado. Destarte, o mercado relevante é aquele que se compõe de produtos concorrentes", conforme dispõe Varella. (2001, p.80).

Na comunidade européia a questão da delimitação do mercado relevante, ainda partindo-se da intelecção do autor, a quem a compreensão de mercado de produtos assenta-se a de mercado relevante, tem-se:

"um mercado de produtos compreende a totalidade de produtos que, são particularmente aptos a satisfazer necessidades homogêneas e que são intercambiáveis com outros produtos somente de forma limitada, em termos de preços, utilização e da preferência dos consumidores. A análise dos produtos pertinentes, se limitada às suas características objetivas, 
pode não ser suficiente: as condições concorrenciais e a estrutura da oferta e procura também devem ser levadas em conta ${ }^{2}$ ". (2001, p. 82).

A noção de mercado relevante, portanto, comporta três dimensões: a da procura, a da oferta e a da dimensão geográfica.

Analisando-se a dimensão da procura, deve-se ter em consideração os produtos genericamente idênticos, bem como aqueles que sejam considerados como bons substitutos. Desta análise caberá, por conseguinte, o levantamento da elasticidade da procura, conquanto seja esta a expressão indicativa da razão da variação da procura em função das variações de preço, tal qual já explicitado supra, e ainda a da elasticidade cruzada da procura, que é a expressão da variação da procura por um determinado produto em função de variações de preço de outro produto o qual lhe possa ser substituto.

Conforme seja a elasticidade cruzada alta, ou seja, quando a variação do produto analisado provocar um grande aumento na procura do produto substituto, este deverá sim ser incluído no mesmo mercado relevante. Do contrário, quando a elasticidade se revelar baixa, ou seja, a variação de preço do produto em análise não acarretar procura sensível de um produto que lhe possa ser substituto, este não deverá, portanto, ser integrante do mesmo mercado relevante, posto que não se caracteriza enquanto sucedâneo.

Muito embora a elasticidade cruzada tenha grande valia na análise do que se constitui enquanto parte de um dado mercado relevante ou não, ela não deve ser tomada de maneira isolada. Neste ponto, obtempera Sérgio Varella Bruna, seguindo a linha da doutrina econômica norte-americana:

“(...) na realidade, o que limita o poder do agente econômico sobre os preços é a elasticidade da procura de seu produto, e não exatamente a elasticidade cruzada existente entre ele e qualquer outro produto que seja. Medir-se o nível de poder econômico de alguém significa aferir-se a intensidade da razão em que suas vendas caem à medida que os preços sejam aumentados, pouco importando qual seja o motivo de tal redução de vendas, se a substituição por outro produto, ou mesmo a simples privação da necessidade dos consumidores. A elasticidade da procura será necessariamente a resultante de todas as elasticidades cruzadas entre o produto em exame e todos os outros bens existentes". (2001, p. 85).

Eis que a desmesurada ênfase dada à elasticidade cruzada no caso da $D u$ Pont a despeito da elasticidade da procura do papel celofane culminou com uma intelecção errônea do caso, uma vez que da análise do fato concreto caberia sim a equiparação do grau de semelhança entre todos os produtos, no caso materiais flexíveis para embalagens, a equiparação ainda quanto aos insumos utilizados no fabrico destes, se eram aproximados ou não, e ainda

\footnotetext{
${ }^{2}$ GOYDER, D.G. Competition Law. Oxford, Clanrendon Press, $2^{a}$ edition, p.346, em menção na obra de Sérgio Varella Bruna. Texto original: "a product market comprises the totality of the products which, with respect to their characteristics, are particularly suitable for satisfying constant needs and are only to a limited extent interchangeable with other products in terms of price, usage and consumer preference. An examination limited to the objective characteristics only of the relevant products cannot be sufficient: the competitive conditions and structure of supply and demand on the market must also be taken into consideration".
} 
quanto ao design e a tecnologia de produção, uma vez que a observância destas equivalências é que permitiriam definir se os produtos em comparação integravam o mesmo mercado relevante ou não, e não tão somente a análise da elasticidade cruzada, que acabou por definir o mercado relevante como sendo composto por todas as espécies de materiais flexíveis para embalagens, descaracterizando o poder econômico inerente a empresa vez que seu produto - o papel celofane, fora remetido a uma análise comparativa frente a um universo amostral de produtos que factualmente não lhe eram concorrentes diretos.

Varella Bruna ressalta ainda, como viço na doutrina econômica americana, que é cabível também a observância de movimentações de preço entre produtos comparados, para fins de categorização no mesmo mercado relevante ou não, ou seja, análises quanto a oscilações de preço no decorrer do tempo de um produto em relação a outro. Verificando-se que quando o preço de um aumenta o do outro também aumenta, ou se cai o de um o do outro também cai, a semelhança entre eles denota que estes fazem parte do mesmo mercado relevante. Tal análise também não se verificou no caso Du Pont, o que mais uma vez deflagra a inconsistência e insuficiência analítica de dados os quais o caso concreto demandava, convergindo para a errônea sentença decretada que supra se observou.

O mercado relevante também deverá ser perquirido segundo a oferta. Nesta análise deve-se ter em foco a possibilidade de entrada de novos competidores e a capacidade dos atuais concorrentes aumentarem sua produção ou passarem a produzir o determinado bem em análise.

Sendo possível identificar empresas as quais detenham a possibilidade de redimensionar recursos da sua produção produzindo bens semelhantes ao analisado, esta deve ser incluída no mercado relevante, ou quando se verifique que apesar de ainda inexistentes, se observe notória facilidade ao seu ingresso no mercado dado ser observáveis baixas barreiras à sua entrada.

A determinação do mercado relevante sob o foco da delimitação geográfica, por sua vez, pressupõe determinar a área em que as empresas nela situadas tenham uma vantagem de custo sobre as empresas localizadas fora dessa mesma área. Isso permitirá às empresas nela incluída estabelecer seus preços tanto acima dos níveis competitivos quanto maior for a magnitude dessa vantagem de custos. Conforme aduz Sérgio Varella Bruna:

"O comportamento dos preços nas diversas localidades geográficas assumirá especial importância ao examinar-se a adequação de incluí-las ou não em um mesmo mercado relevante. Isso porque os preços em determinadas áreas podem estar limitados tanto pelas vendas efetivas de produtos de outra área, como também pela mera potencialidade de essas vendas virem a concretizar-se em casos de aumento de preços. Desse modo, se nas diversas localidades em exame se verificar uma variação uniforme de preços, mesmo que não tenha havido intercâmbio efetivo de mercadorias, isso será indicativo de que todas elas devam ser incluídas no mesmo mercado relevante. Hipótese diversa se verificará quando uma dada variação de preços em uma das localidades não for acompanhada pelas demais, o que sugerirá que esta determinada área constitui por si só um mercado relevante apartado dos demais". (2001,p. 95). 
Eis que para a determinação da delimitação geográfica de um mercado relevante faz-se necessário analisar a viabilidade dos custos de transporte e preço unitário do produto. Este, ao chegar na localidade de venda, deve ter custo competitivo em relação aos demais a fim de que possa fazer parte do mesmo mercado relevante.

Assim, a análise do mercado relevante se faz primordial posto que esta visualização é que permite ater-se ao universo amostral concorrencial no qual certa empresa encontra-se inserida a fim de que se proceda a efetiva análise do quão decisiva é a sua atuação frente aos seus concorrentes, no que toca a determinação do preço do produto, delineando, conseguintemente, a manifestação abusiva do exercício de seu poder econômico ou sua mera participação na cíclica de mercado conforme se verifique seu grau de influência econômica perante seus concorrentes.

\section{O PODER ECONÔMICO}

Da delimitação do que se constitui enquanto mercado relevante insurge a noção de poder econômico.

A Constituição Federal vigente, no artigo 173 parágrafo $4^{\circ}$ estabelece que "a lei reprimirá o abuso do poder econômico que vise à dominação de mercados, à eliminação da concorrência e ao aumento arbitrário dos lucros". Neste ponto denota-se o poder econômico como um dado estrutural da própria ordem econômica haja vista que a lei reprime apenas o seu abuso manifestado de acordo com as condutas supra mencionadas, de forma que o poder em si se traduz em prerrogativa inerente aos agentes econômicos atuantes no mercado conforme a intelecção do próprio parágrafo.

Muito embora a norma traga insculpida esta irrefutável noção, denota-se controversa a observância de que os agentes econômicos detêm o direito constitucional de atuarem livremente no mercado enquanto que a mesma norma dá guarida ao exercício do poder econômico destes, exercício este que acaba por limitar, dirimir e segregar a atuação livre dos agentes econômicos detentores de inferior poder econômico.

Neste diapasão cabível faz-se verificar o tênue limite no qual reside a manifestação do poder econômico e a sua conduta abusiva, dado que apenas esta última deflagra conduta punível.

\section{O ABUSO DE PODER ECONÔMICO}

A temática do Abuso do Poder Econômico detém trato constitucional desde a Carta de 1934 quando se adotou a figura da defesa da "economia popular" no artigo 171 do referido diploma legal. Desde então seguiu-se a tutela da disciplina que com o passar dos anos foi adquirindo sucessivos epítetos e atingindo diferentes alcances dada a circunstância vivificada pelo legislador constituinte.

$\mathrm{Na}$ Constituição de 1937 os "crimes contra a economia popular" foram equiparados aos "crimes contra o Estado" no artigo 191, vindo a ter na Constituição de 1946, no artigo 148, 
uma abordagem ampliada, quase como a que hoje se identifica na atual Constituição vigente onde lia-se:

Art. 148. "A lei reprimirá toda e qualquer forma de abuso do poder econômico, inclusive as uniões ou agrupamentos de empresas individuais e sociais, seja qual for sua natureza, que tenham por fim dominar os mercados nacionais, eliminar a concorrência e aumentar arbitrariamente os lucros".

A Constituição de 1967, por sua vez, elevou o dispositivo à categoria de princípio do artigo caput do Título "Da Ordem Econômica e Social”, tendo-se:

Art. 157. "A ordem econômica e social tem por fim realizar a justiça social, com base nos seguintes princípios:

VI - Repressão ao abuso do poder econômico, caracterizado pelo domínio dos mercados, a eliminação da concorrência e o aumento arbitrário dos lucros.

A Emenda Constitucional $\mathrm{n}^{\circ} 1$ de 1969 acrescentou o "desenvolvimento nacional" ao caput, do artigo 160, detendo a seguinte redação:

Art. 160. "A ordem econômica e social tem por fim realizar o " desenvolvimento nacional' e a justiça social, com base nos seguintes princípios:

V - Repressão ao abuso do poder econômico, caracterizado pelo domínio dos mercados, a eliminação da concorrência e o aumento arbitrário dos lucros.

A atual Constituição tão somente promoveu o princípio a uma condição das formas de exercício da atividade econômica, com a mesma redação mantida nas Cartas anteriores, mas enquanto parágrafo $4^{\circ}$ do artigo 173 , tal qual já supra descrito. E nesta acepção o abuso do poder econômico se perfaz quando da observância de condutas tendentes à dominação de mercados, do ímpeto de eliminação da concorrência e do aumento arbitrário dos lucros.

Eis que a tentativa de dominação de mercados se consubstancia como sendo uma das condutas possivelmente atentatórias ao livre exercício da atividade econômica indutoras da manifestação abusiva do poder econômico do agente, quando da elucidação de mecanismos de concentração, que pela robustez dos recursos agregados que as empresas concentradas passam a deter, acabam dirimindo a atuação dos concorrentes com inferior poder econômico, posto que dada a ausência de condições minimamente paritárias de competitividade, submergem diante das distorções concorrenciais que tais formações empresariais desnudam vez que estas formações passam a ditar os preços no mercado 
remetendo seus concorrentes à condição de sujeição tal qual analisado supra na estrutura oligopolista de mercado.

No que tange ao ímpeto de eliminação da concorrência, esta também se deflagra enquanto mecanismo de concretização do exercício arbitrário de poder econômico uma vez que suscita a impetração de barreiras à entrada de novos concorrentes no mercado por parte dos agentes já atuantes.

Muito embora seja uníssono que a elucidação de mecanismos que se concretizam em barreiras à entrada de concorrentes denote o exercício abusivo da manifestação do poder econômico, seja por parte de uma única empresa, grupo de empresas ou conglomerados empresariais, a doutrina, porém, ainda é dissonante quanto ao que seja propriamente "barreiras à entrada", se atinente ao potencial que as empresas que já estão no mercado tem de elevar seus preços de venda acima dos custos médios mínimos de produção e distribuição, ou se os custos que devem ser suportados pelos novos concorrentes, mas que não os tenham sido suportados por aqueles que anteriormente adentraram o mercado.

O discrepante posicionamento, no entanto, tem aglutinado maiores adeptos a esta segunda acepção, prevalecendo, por conseguinte, no âmbito doutrinário da tutela da concorrência.

Eis que se entende por barreiras todos os fatores existentes em um dado mercado que permitam às empresas nele atuantes auferir preços superiores aos puramente competitivos sem serem ameaçadas pela entrada de novos concorrentes dada a inobservância de condições favoráveis de competitividade haja vista as dificuldades suscitadas pelas empresas já atuantes.

Assim os fatores que se deflagram enquanto barreiras a novos entrantes são todos aqueles capazes de influenciar negativamente a livre atuação dos agentes no intuito de adentrar o mercado vez que as barreiras impostas pelos agentes econômicos já instalados lhes permitem elevar seu preço além do nível competitivo, sem sofrer intensificação da concorrência.

A análise das barreiras, no entanto, concentra-se numa esfera subjetiva, cabendo, por conseguinte, a análise do caso concreto, posto que podem ser consideradas barreiras todos os fatores que possam limitar a entrada de um novo concorrente, de maneira que o que possa se constituir em barreira para um determinado entrante pode não o ser para outro.

Apesar do caráter subjetivo, a literatura de organização industrial classifica as barreiras à entrada de novos concorrentes em quatro tipos genéricos: as barreiras de diferenciação do produto, as decorrentes de vantagens absolutas de custo, as resultantes da presença de economias de escala e as barreiras decorrentes da exigência de investimentos iniciais elevados.

As barreiras de diferenciação do produto, tal qual pontuam Fagundes e Pondé, (1998), decorrem da presença de elementos que tornam os produtos ou serviços ofertados pelas empresas já existentes mais vantajosos aos olhos dos consumidores, e esta vantagem pode estar relacionada ao fato de a empresa deter o controle do acesso à tecnologia necessária para o seu desenvolvimento através de mecanismos legais de controle da propriedade industrial ou segredos industriais, ou ainda correlatos a um alto gasto efetivado com publicidade, induzindo à fidelização dos consumidores, dificultando, conseguintemente a competitividade de novos produtos similares frente a estes já consolidados no mercado. 
A durabilidade e a complexidade dos produtos também podem se consubstanciar em barreira à entrada de novos concorrentes posto que induzem o possível novo entrante a dispender considerável tempo e recursos financeiros a fim de convencer os consumidores da qualidade de seu produto, bem como a presença de práticas e canais de distribuição específicos que limitam a utilização de determinadas formas de acesso ao consumidor para novos concorrentes, como contratos de exclusividade com revendedores.

No tocante às vantagens absolutas de custo, ainda seguindo a linha de Fagundes e Pondé, estas são decorrentes da observância do fato de que as empresas já existentes têm acesso exclusivo a determinados ativos ou recursos que lhes permite fabricar com a mesma escala de produção de um possível novo entrante a um custo menor. Tal prerrogativa pode ser decorrente da pretérita capacitação de recursos humanos, dificultando o recrutamento de pessoal adequado por parte do novo entrante; da disponibilidade de tecnologia restrita às empresas já estabelecidas, seja devido a dificuldades de imitação ou a mecanismos legais de propriedade intelectual; da compra de matérias primas mais baratas devido a contratos de exclusividade ou a compras em grandes volumes, e ainda em razão do menor custo para a obtenção de capital dada a maior disponibilidade de fundos próprios ou mesmo da captação de recursos junto a terceiros vez que a consolidação da empresa no mercado através do tempo geralmente lhe confere maior confiança creditícia.

Segundo Varella, no que toca às barreiras resultantes da presença de economias de escala, elas decorrem do fato de que uma empresa detentora de poder econômico poderá exercer sua política de preços dimensionando seus lucros excedentes em níveis inferiores tornando não atraente a entrada de novos concorrentes. Para o mestre a escala mínima de eficiência, por outro lado, poderá ser de tal magnitude que o concorrente potencial possa prever que o preço decorrente do aumento de oferta, ocasionado por seu ingresso, viria a ser de tal forma reduzido que sua entrada no mercado não se justificaria economicamente, e Seguindo esta linha, ele arremata:

“(...) o grau de elevação do preço de equilíbrio acima daquele que seria o preço puramente concorrencial dependerá da maior ou menor facilidade com que novos concorrentes, atraídos pelos lucros excedentes, possam ingressar no mercado, intensificando a concorrência, e, conseguintemente, baixando o nível de preços. Portanto, o nível de equilíbrio é influenciado não pela concorrência real ou efetiva, senão também pela concorrência potencial ou iminente. Quando o ingresso no mercado seja extremamente fácil, ainda que seja alto o nível de concentração, as empresas nele atuantes deverão estabelecer seus preços mais proximamente ao nível competitivo, já que, no caso de lucros excessivos, novos concorrentes ingressarão no mercado aumentando a oferta e reduzindo os preços". (2001, p. 56).

Eis que tentando coibir tal ímpeto, atua o monopolista dimensionando seus lucros para baixo.

No que atine às barreiras decorrentes de investimentos iniciais elevados, estes são tocantes aos recursos financeiros a serem investidos na efetiva entrada do potencial concorrente no mercado. Conforme ressalta Sérgio, nesta noção englobam-se os investimentos a fundo perdido, estes que não podem ser reavidos pela realocação dos fatores de produção fora do mercado relevante, como os gastos com publicidade ou com equipamentos altamente 
especializados. Assim, quando os investimentos iniciais se deflagrarem demasiadamente altos, as possibilidades de um potencial concorrente adentrar ao mercado será menor de forma que ao monopolista ser-lhe-á imperativo favorecer tal cenário.

Seguindo a linha da doutrina econômica de Areeda e Kaplow, Varela Bruna ressalta a observação dos autores no tocante a três advertências que devem ser feitas quanto ao conceito de barreiras à entrada: elas não têm caráter absoluto, posto que o que pode ser um fator impeditivo para uma empresa pode não o ser para outra; a avaliação da magnitude das barreiras não deve ser realizada tomando como base somente dados objetivos, mas também levando em conta as expectativas individuais dos concorrentes potenciais, uma vez que um possível novo entrante observando lucros modestos pode vir a crer que sua entrada no mercado não ocasionará a eliminação de tais ganhos, como também observando grandes lucros um possível novo entrante pode não achar sua entrada atrativa caso venha a crer que com sua entrada estes lucros sofreriam significativa minoração; por fim deve se ter em mente que as barreiras podem não só obstaculizar a entrada de novos concorrentes, mas também impedir a expansão dos atuais pequenos competidores já atuantes no mercado. (2001, p. 57).

O aumento arbitrário dos lucros também se consubstancia enquanto possível exercício abusivo do poder econômico. Tal mensuração, no entanto, não é de fácil aferição nos casos concretos tais que na análise antitruste o que importa são os lucros econômicos enquanto que as empresas registram as suas operações através de critérios contábeis, onde fatores como a depreciação de bens ou a alocação de custos tornam o resultado econômico substancialmente diverso do resultado contábil. Além disso, tal qual pontua Sérgio Varella Bruna, na contabilidade a vida da empresa é dividida em exercícios sociais, enquanto que a economia encara a empresa focando todo o seu período de existência. (2001, p. 123).

Muito embora haja diferenciações dentro destes dois aspectos, conclusões relevantes podem ser retiradas dos registros contábeis, efetuando-se os devidos ajustes, como:

"o cômputo dos custos de oportunidade de capital ou a reavaliação dos bens já contabilmente depreciados. Por outro lado, deve-se ampliar o período analisado, uma vez que somente lucros persistentes são indicativos de poder econômico, ao passo que lucros eventuais não necessariamente denotam a sua existência”. (2001, p. 124)

Embora as situações descritas denotem possíveis manifestações abusivas do exercício do poder econômico inerente as empresas, elas são antes de tudo ocasiões deflagradoras do poder econômico que dispõe estes agentes econômicos em atuação no mercado, o que deve ser ponto da partida para a análise da tutela da concorrência uma vez que evidenciado este poder não deverá se perquirir a objetiva sanção para o agente uma vez que, conforme já suscitado, a manifestação do poder econômico nos mercados é um componente estrutural, não cabendo, por conseguinte, retaliação a estas manifestações. A tutela da concorrência deve centrar-se nas condutas empresariais que se denotem abusivas, que efetivamente se constituam numa atuação capaz de influenciar os preços dos bens ofertados e na manipulação dos mercados por parte de uma empresa ou grupo de empresas.

Eis assim que a aferição do poder econômico de um agente é ponto de partida para esta análise dado que só poderá haver abuso de poder econômico por parte deste se for 
preexistente a observância de seu poder econômico. Isto posto, todas as expressões da manifestação abusiva do poder econômico das empresas elencadas devem ser analisadas em todos os seus aspectos, levando-se em conta todos os seus pressupostos, seu mercado relevante e âmbito de atuação a fim de que se persiga a real capacidade do agente de controlar preços e manipular mercados mediante sua atuação e não tão somente o exercício do seu poder econômico, o que encontra guarida na própria Constituição vigente, e muitas vezes conduzindo à eficiência econômica, não se traduzindo em elementar a ser coibida posto que seja inerente às distorções que os próprios mercados possuem.

\section{A DEFESA DA CONCORRÊNCIA NO ORDENAMENTO JURÍDICO BRASILEIRO E A ATUAÇÃO DO CADE}

Após a promulgação da Constituição Federal de 1988 que elegeu a livre concorrência como um dos princípios orientadores da ordem econômica nacional, maciçamente a partir da década de 1990, verifica-se na história econômica brasileira um período de abertura da economia às importações, a partir da adequação das tarifas e normas do comércio internacional brasileiro frente às novas regras da Organização Mundial do Comércio OMC, a desregulamentação dos mercados e a privatização de empresas estatais, juntamente com a liberação dos preços culminando com o novo ordenamento econômico do plano Real. Além disso, a eliminação progressiva de subsídios e a introdução de concepções de equilíbrio fiscal e monetário deu início a um processo de estabilidade econômica observável a partir do ano de 1994.

Este novo quadro suscitou a insurgência de um diploma legal o qual desse suporte as novas perspectivas principiológicas constitucionais instituídas e ao mesmo tempo se coadunasse à nova conjuntura econômica que se delineava no âmago do cenário econômico brasileiro.

Eis que a lei 8.884 de 11 de junho de 1994 que transformou o Conselho Administrativo de Defesa Econômica - CADE, em autarquia vinculada ao Ministério da Justiça elevando este Conselho à condição de órgão da esfera administrativa com função de julgar as infrações à ordem econômica, vinculado à Secretaria de Direito Econômico - SDE, órgão do Ministério da Justiça ao qual incumbe acompanhar, permanentemente, as atividades e práticas comerciais de pessoas físicas ou jurídicas que detiverem posição dominante em mercado relevante de bens ou serviços, a fim de prevenir infrações de ordem econômica, proceder a averiguações preliminares em face de indícios, e instaurar processos administrativos para apuração de infrações atentatórias à ordem econômica, remetendo, de ofício, para o CADE, para julgamento os processos quando entender configuradas infrações, ou mesmo quando decidir pelo arquivamento, deu início a um processo de reformulação da tutela jurídica nacional de defesa da concorrência, garantindo um cenário coevo à nova realidade econômica e estrutural vivificada na sociedade brasileira.

Eis assim que à Secretaria de Direito Econômico - SDE, é cabível a adoção de medidas preventivas que conduzam à cessação da prática de infração, celebrar estes compromissos de cessação submetendo ao CADE a fiscalização e seu cumprimento, devendo ainda instruir processos a serem julgados pelo CADE, inclusive consultas, além da fiscalização do cumprimento das decisões do CADE. 
Ao CADE compete decidir sobre a existência de infração à ordem econômica e aplicar as penalidades previstas em lei. Nos termos do artigo $4^{\circ}$ da lei 8.884 de 1994 , o plenário do CADE é composto por um Presidente e seis conselheiros escolhidos entre cidadãos com mais de trinta e cinco anos de idade nomeados pelo Presidente da República, depois de aprovados pelo Senado Federal, com mandato de dois anos admitida uma recondução tal qual disposto no $\S 1^{\underline{o}}$.

O CADE conta ainda com uma Procuradoria-Geral com funções de prestar-lhe assessoria e defendê-lo em juízo, promover a execução judicial de suas decisões e julgados e requerer com autorização do Plenário, medidas judiciais visando à cessação de infrações de ordem econômica, conforme disposto no artigo 10.

Assim, são infrações à ordem econômica às quais cabe a tutela do CADE os atos que tenham por objeto ou possam produzir os seguintes efeitos, ainda que não sejam alcançados: limitar, falsear, ou de qualquer forma prejudicar a livre concorrência ou a livre iniciativa; dominar mercado relevante de bem ou serviço; aumento arbitrário dos lucros; e o exercício de forma abusiva de posição dominante.

Para o infrator da ordem econômica a lei prevê (artigo 23) as seguintes sanções: "I no caso da empresa multa de 1 a $30 \%$ do valor do faturamento bruto no seu último exercício, excluídos os impostos, a qual nunca será inferior à vantagem auferida quando quantificável; II - no caso de administrador, direto ou indiretamente responsável pela infração cometida por empresa, multa de 10 a $50 \%$ do valor daquela aplicável à empresa, de responsabilidade pessoal e exclusiva ao administrador. III- no caso das demais pessoas físicas ou jurídicas de Direito Público ou Privado, bem como quaisquer associações de entidades ou pessoas constituídas de fato ou de direito, ainda que temporariamente, com ou sem personalidade jurídica, que não exerçam atividade empresarial, não sendo possível utilizar-se do critério do valor do faturamento bruto, a multa será de 6.000 (sis mil) a 6.000.000 (seis milhões) de Unidades Físicas de Referências (UFIRs), ou padrão superveniente. Em caso de reincidência, as multas cominadas serão aplicadas em dobro (parágrafo único do artigo 23)".

Ante a gravidade dos fatos ou em vista do interesse público, podem ser ainda impostos ao infrator, isolada ou cumulativamente (artigo 24), as seguintes penas: (I) a publicação, por dois dias seguidos, de uma a três semanas consecutivas, do extrato da decisão condenatória, em meia página e às expensas do infrator, em jornal indicado na decisão; (II) proibição de participar, por no mínimo cinco anos, de licitação de qualquer esfera de governo, seja na Administração Direta, Indireta, ou de, neste prazo, contratar com instituições financeiras oficiais.; (III) inscrição no Cadastro Nacional de Defesa Do Consumidor; (IV) recomendação aos órgãos públicos competentes para que: seja concedida licença compulsória de patentes de titularidade do infrator; sejam-lhe cancelados, no todo ou em parte, incentivos fiscais ou subsídios públicos, ou negados parcelamentos de tributos federais; além disto, pode ser-lhe imposta a cisão da sociedade, a transferência do controle societário, venda de ativos, cessação parcial de atividade, ou qualquer outro ato ou providência necessários para a eliminação dos efeitos nocivos à ordem econômica manifestos.

Havendo a continuidade dos atos ou situações que configurem infração da ordem econômica após decisão do Plenário do CADE determinando sua cessação, ou pelo descumprimento de medida preventiva, o responsável fica sujeito a multa diária de valor 
não inferior a 5.000 UFIRs, Unidades Fiscais de Referência, ou padrão superveniente, podendo ser aumentada em até 20 vezes se assim o recomendarem sua situação econômica e a gravidade da infração (artigo 25).

Assim o CADE é pela sua própria competência um órgão judicante embora suas decisões não constituam sentença no sentido de fazerem coisa julgada, tendo sido tomado "como um 'quase-tribunal', uma espécie de prenúncio do Tribunal Administrativo" conforme dispõe Washington Peluso, (2005, p 263), detendo paulatinamente cada vez mais relevância dado que é crescentemente solicitada sua atuação dada a maior conveniência encontrada nas soluções administrativas negociadas na área de competência do CADE, frente às habituais delongas das lides judiciais.

Eis que seu caráter de tribunal administrativo não pode ser suscitado pelas partes objetivando o descumprimento das decisões pelo órgão arroladas posto que elas detêm força coativa, devendo ser de execução imediata, sob pena de sanção. Às decisões do CADE só serão de cabível descumprimento quando levadas a provimento em juízo comum, e este prolatar uma sentença contrária a decisão instituída pelo órgão.

Neste ímpeto é imperativo ao CADE julgar os processos nos quais se evidenciam condutas contrárias aos paradigmas constitucionais tocantes à ordem econômica, tal como no processo de número 08012.003118/2005-85 julgado no ano de 2005, que tem como relator o conselheiro Luís Fernando Schuartz. O processo administrativo é tocante a uma cláusula de exclusividade instituída num contrato estabelecido entre uma cooperativa de médicos. $\mathrm{O}$ caso é deflagrado como prática restritiva à livre concorrência e de exercício abusivo de posição dominante, tendo parecer favorável pela condenação, uma vez que a Unimed de Pindamonhangaba, empresa em questão, demonstra indícios dessa prática quando apresenta em seu Estatuto dispositivo tocante ao fato de que os médicos integrantes de sua cooperativa estão impedidos de atender convênios que concorram com a mesma, justificando esta cláusula como sendo uma maneira de viabilizar a atividade através da criação de condições que lhe possibilite concorrer com os demais planos de saúde.

Ao contrário do que foi afirmado a não exclusividade dos médicos cooperados é que possibilitaria que a Cooperativa se desenvolvesse sem que houvesse a eliminação de outros interesses relevantes para a sociedade propriamente tutelados no ordenamento jurídico nacional, como a defesa do consumidor e da livre concorrência (art. $5^{\circ}$, inciso XXXII, e art. 170, incisos IV e V, da Constituição Federal). Eis que é cabível à cooperativa cumprir sua função social e não apenas atender aos interesses corporativos de seus dirigentes dado que no caso em deslinde o mercado relevante definido pela SDE foi definido como sendo o de prestação de serviços médicos por meio de planos de saúde.

Eis que assim, do ponto de vista geográfico, restringiu-se a área de atuação da representada, abrangendo as cidades de Lagoinha, Pindamonhangaba e Santo Antonio do Pinhal, todas situadas no Estado de São Paulo. Nesta seara, conforme constante dos autos do processo, a Unimed Pindamonhangaba possui 110 médicos cooperados, sendo que o Conselho Regional de Medicina do Estado de São Paulo possui 253 médicos credenciados que prestam serviços nesta localidade, ou seja, na área de atuação da representada. Assim, a Unimed Pindamonhangaba conta com aproximadamente $43 \%$ dos médicos de sua área de atuação o que irrefutavelmente deflagra sua tentativa de dominação de mercado, haja vista o elevado percentual comparativamente ao adotado na lei 8.884 para a apreciação dos casos de concentração que é de $20 \%$ do mercado relevante conforme artigo $54, \S 3^{\circ}$. 
Eis que o CADE, através do seu relator conselheiro opinou pela condenação da Unimed Pindamonhangaba pela prática de infração tipificada nos artigo 20 , incisos I e IV, tocantes à atuação manifestamente favorável ao prejuízo da livre concorrência e da livre iniciativa e quanto ao exercício abusivo de posição dominante; além de incursão no artigo 21, incisos IV e $\mathrm{V}$ atinentes ao exercício de atividade limitadora ou impeditiva de acesso ao mercado por parte de novas empresas, bem como da elucidação de mecanismos obstativos "à constituição, ao funcionamento ou ao desenvolvimento de empresa concorrente ou de fornecedor, adquirente ou financiador de bens ou serviços", conforme dispostos na Lei $\mathrm{n}^{\mathrm{o}}$ 8.884/94, sugerindo ainda a conseqüente aplicação da multa prevista no artigo 23, inciso III da referida lei, no qual a multa estabelecida se encerra entre 6.000 e 6.000 .000 de Unidades Fiscais de Referência (Ufir).

\section{A TUTELA DA CONCORRÊNCIA NO ÂMBITO NORMATIVO INTERNACIONAL}

Conforme analisado supra as praticas anti-concorrenciais são fenômenos que se exprimem além das fronteiras nacionais dada a pujança com que o fenômeno da globalização remete os mercados, dando ensejo a atuação das grandes corporações empresariais internacionais as quais diante da robustez de seus recursos, adentram ambientes nacionais valendo-se de prerrogativas econômicas próprias, e dada a prevalência do poder econômico inerente a estas empresas, elas acabam por suplantar a legislação nacional, destoando seus fins empresariais frente às diretrizes norteadoras da disciplina econômica dos países sobre os quais recaem seu âmbito de atuação.

Neste sentido a relevância da criação e consolidação de um sistema de cooperação internacional entre as autoridades da concorrência, reforçando a aplicação de um Direito supranacional de tutela da concorrência seria de indubitável préstimo para a comunidade internacional uma vez que dissiparia as possibilidades de conflito de leis alienígenas, limitando o risco de discrepâncias decorrente da aplicação extraterritorial de diferentes leis de defesa da concorrência e da realização de inquéritos por diferentes autoridades. Tal sistema, portanto, traria maior segurança jurídica nas trocas comerciais internacionais, além de que diminuiria custos processuais com a instauração de vários processos em diversas jurisdições.

A Organização Mundial do Comércio, conforme seja o órgão regulamentador das relações de troca internacionais e promotor do livre comércio, servindo de palco para a resolução de controvérsias comerciais, embora possua funções executivas, legislativas e judiciárias no âmbito do comércio internacional, não detém legislação específica tocante a tutela da concorrência. Em vários instrumentos legais da OMC podem ser encontrados dispositivos $^{3}$ relacionados com os princípios da política da concorrência, mas não há factualmente uma legislação específica, voltada para o trato de questões práticas focadas na atuação dos agentes econômicos em desalinho aos imperativos concorrenciais de mercado.

\footnotetext{
${ }^{3}$ Vide seção 1.1. do Quarto Protocolo do GATT, nos artigos VIII, IX (1 e 2) do GATS, no artigo 9 do TRIMS, no artigo 41 do TRIPS e ainda nas Recomendações da OMC em relação à Domestic Regulation in the Accountancy Sector.
} 
Iniciativa de âmbito internacional que merece destaque neste âmbito é a desenvolvida pela Organização para Cooperação e Desenvolvimento Econômico - OCDE. A OCDE foi criada em 1960, e atualmente mantém relações com mais de 70 países entre membros efetivos e não membros.

A organização é estruturada em diversos Diretórios, subdivididos em Comitês que se reúnem periodicamente na sede situada em Paris. Estes atuam principalmente na área social e econômica, abordando temas como macroeconomia, comércio, desenvolvimento, educação, ciência e inovação.

Entre seus objetivos estão fomentar a boa governança estatal e empresarial, o desenvolvimento social e o crescimento econômico por meio de cooperação institucional e política, assim como a utilização de mecanismos de monitoramento. Para a consecução de tais objetivos, utiliza mecanismos como a realização de pesquisas e estatísticas, reuniões periódicas, intercâmbio de experiências e best practice.

No que tange à tutela da concorrência o órgão responsável por tal temática é o Diretório para Assuntos Financeiros e Empresariais, sob o qual funciona o Comitê de Concorrência. O Comitê conta com dois Grupos de Trabalho, sobre Concorrência e Regulação e o Grupo sobre Cooperação e Implementação. Foi estabelecido, ainda, um Grupo Conjunto de Comércio e Concorrência, sob égide do Diretório de Comércio.

O Comitê de Concorrência (COMP) foi criado em 1961 e desde então teve seu mandato periodicamente renovado.Entre os objetivos do COMP estão a monitoração e a revisão do desenvolvimento de políticas e legislação de concorrência em países e organizações internacionais; o exame e análise de temas de política e legislação de concorrência levando em conta a interação entre concorrência e outras políticas governamentais; a promoção da cooperação entre membros na elaboração e na implementação de políticas e legislação de concorrência; a cooperaração com outros comitês da organização em temas relacionados à concorrência; a troca de informações sobre temas de concorrência surgidos em outros foros e o relato e cumprimento das recomendações ao Conselho diretor da OCDE, composto por representantes dos países membros, sobre temas dentro das competências do Comitê.

O Comitê reúne-se três vezes por ano, em eventos denominados "Semana da Concorrência", nos quais ocorrem além das reuniões do Comitê, os encontros dos Grupos de Trabalho e do Grupo Conjunto. Em fevereiro ocorre concomitantemente o Global Forum on Competition. Participam deste Fórum autoridades da concorrência de países membros, não-membros, observadores e organizações não-governamentais. São tratados tópicos de interesse específico de países em desenvolvimento, sugeridos antecipadamente nas reuniões do Comitê.

O Comitê também promove o Latin American Forum on Competition, em cooperação com o Banco Interamericano de Desenvolvimento (IADB). O encontro ocorre anualmente e trata de temas de interesse dos países participantes além de discutir o peer review realizado em um país da região. Em 2005 o Brasil passou por este processo de revisão.

O grupo de trabalho 2 tem por objetivo revisar, analisar e fazer recomendações em temas de concorrência relacionados à criação, operação, reforma e desmantelamento de regimes regulatórios setoriais ou de alcance econômico geral. Já o grupo de Trabalho 3 foi criado em 1964 para tratar de temas relacionados à cooperação e sua implementação. Seus 
objetivos são relacionados a dois tópicos principais: os procedimentos de controle de fusões e os cartéis clássicos.

O Grupo Conjunto de Comércio e Concorrência, por sua vez, foi criado em 1996, visando analisar e discutir políticas relacionadas a acesso de mercados como escopo e cobertura, assim como implementação de legislação de defesa da concorrência; opções internacionais para aumentar a coerência de políticas de comércio e concorrência; efeitos de medidas e políticas de concorrência no comércio; e efeitos da regulamentação de acesso a mercados e do processo concorrencial.

A Conferência das Nações Unidas sobre Comércio e Desenvolvimento - UNCTAD, também desenvolve estudos na área da tutela da concorrência. A organização estabelecida em 1964 em resposta às exigências dos países com menor nível de desenvolvimento os quais almejavam o estabelecimento de um foro diplomático internacional permanente que tivesse como cerne a discussão de políticas e ações para o desenvolvimento, é o principal órgão do sistema das Nações Unidas para o tratamento integrado entre comércio e desenvolvimento, assim como de assuntos correlatos às áreas de finanças, tecnologia, investimento e desenvolvimento sustentável.

É um fórum intergovernamental permanente e subsidiário à Assembléia Geral das Nações Unidas. Os seus diversos encontros, pesquisas e programas de cooperação técnica visam auxiliar os países em desenvolvimento a se integrarem no âmbito da economia mundial.

A organização é estruturada através da Conferência Ministerial, órgão máximo no processo decisório responsável pela administração da organização, pelo estabelecimento do programa de trabalho quadrienal e pelas discussões de temas atuais do comércio e desenvolvimento, pela Diretoria de Comércio e Desenvolvimento e por Comissões Especiais, subordinadas à Diretoria e apoiadas por grupos de especialistas.

A militância política da UNCTAD no campo da concorrência iniciou-se nos anos 70, quando países em desenvolvimento, em particular, advogaram por um trabalho sobre práticas empresariais restritivas (PERs).

Essas exigências resultaram em negociações de um código multilateral de conduta sobre PERs e na adoção, em 1980, pela Assembléia Geral das Nações Unidas de uma Série de Acordos Multilaterais de Princípios e Regras Equitativas para o Controle de Práticas Empresariais Restritivas (conhecida como Série de PERs). Até hoje, a Série sobre PERs continua sendo o único instrumento multilateral completo sobre política e legislação de concorrência.

Para monitorar e revisar o trabalho de implementação da Série de PERs a UNCTAD criou dois órgãos institucionais: O Grupo Intergovernamental de Especialistas em Política e Legislação de Concorrência, que realiza fóruns anuais para consultas, discussões e trocas de visões entre os Estados com relação à Série PERs, que também tem como atribuição produzir estudos e pesquisas periódicas sobre a política de concorrência; e As Conferências de Revisão das Nações Unidas, que revisam a Série sobre PERs, e são realizadas a cada cinco anos, tendo sido a última realizada no ano de 2005.

Muito embora tais iniciativas detenham indubitável contributo no que toca ao estudo e desenvolvimento de políticas tocantes a salutar atuação dos agentes econômicos no que se refere às praticas concorrenciais, faz-se cabível ressaltar que estas diretrizes suscitadas por 
estas organizações não possuem nenhuma força vinculante mesmo para a atuação de empresas oriundas de países membros destas organizações. Elas servem de fundamento ideológico e político, porém resvalam na total inoperância concreta de seus dispositivos posto que não se consubstanciam em regramentos de âmbito internacional, mas tão somente em estudos e apontamentos indicativos da salutar atuação dos agentes econômicos, porém sem qualquer força coativa dado que não se tratam de normas de observância supranacional, mas de meras recomendações.

No ímpeto de se perquirir a formulação de um dispositivo supranacional com vistas a tutela da concorrência, no ano de 1999 em Seattle grupos de trabalho da OCDE apresentaram relatórios ${ }^{4}$ acerca da necessidade de ciação de um diploma legal com este fim no âmbito da OMC, porém,embora haja consenso de que em razão da globalização do comércio internacional, o número de práticas anticoncorrenciais que provocam efeitos em mais de uma jurisdição tenha efetivamente aumentado, e de que a formulação e aplicação de uma legislação de defesa da concorrência viria a complementar e reforçar o processo de liberalização do comércio internacional, há vários posicionamentos dissonantes entre os países envolvidos, como os Estados Unidos que não vê na $\mathrm{OMC}$ o foro adequado para discutir problemas de concorrência internacionais, possuindo a política da concorrência objetivos diversos da política comercial e tem uma preferência pela assistência técnica e pela celebração de acordos bilaterais de cooperação, diferentemente da comunidade européia que se posiciona favorável à criação desta legislação no âmbito da OMC.

Além disso, têm-se as diferenças de desenvolvimento da política e do direito da concorrência entre os países membros da OMC, o que torna ainda mais complexo o processo de "harmonização" das regras e princípios da concorrência a nível mundial. Somado a isto não se tem com exatidão o âmbito de aplicação destas normas na economia, se seria atinente a todos os seguimentos ou restrita a alguns.

Eis que das dissonâncias suscitadas, soou apenas um razoável consenso sobre a necessidade de se discutir a possibilidade de inclusão de regras de concorrência no âmbito da OMC, mas até então este vácuo ainda não fora suplantado. Resta aos países, inclusive ao Brasil, a elucidação de acordos bilaterais, e no que toca ao Mercosul, deverá ser igualmente intentada uma harmonização das legislações nacionais e a cooperação entre as autoridades de defesa da concorrência nacionais, com fulcro em aspectos procedimentais, como por exemplo notificações e troca de informações ou documentos dado que o fortalecimento do Mercosul dará mais força ao Brasil nas discussões no âmbito da OMC, permitindo a melhor defesa dos seus interesses, o que também trará vantagens para os outros Estados membros do bloco.

\section{CONSIDERAÇÕES FINAIS}

O cenário monopolista de mercado é uma indubitável estrutura consolidada vez que a desenfreada busca pelo lucro calcada na eficiência econômica é irrefutavelmente alcançada mediante a elucidação de mecanismos empresariais de concentração dado que pressupõe o

\footnotetext{
${ }^{4}$ Vide Report (1997) of the Working Group on the Interaction between Trade and Competition Policy to the General Concil (WT/WGTCP/1); Report (1998) of the Working Group on the Interaction between Trade and Competition Policy to the General Concil (WT/WGTCP/2); Report (1999) of the Working Group on the Interaction between Trade and Competition Policy to the General Concil (WT/WGTCP/3).
} 
carreamento de políticas e ações comuns em prol da obtenção do lucro máximo garantidor de uma permanência sustentável no seio do mercado.

Neste ponto denota-se irreversível a estrutura concorrencial concentrada, de forma que se faz cabível aos operadores do Direito garantir a disciplina de tais conformações vez que se traduzem em elementares inerentes às estruturas mercadológicas hodiernas, que, no entanto, devem encontrar limitações legais que parametrizem sua atuação sob pena de se ver cerceada a liberdade de atuação dos demais agentes econômicos, em incomensurável violação às próprias bases principiológicas sobre as quais se sustém a ordem institucional nacional.

Eis que a elucidação do diploma legal brasileiro instituído pela lei 8.884 de 1994 norteador das práticas concorrenciais representou um grande avanço no que tange à tutela da concorrência haja vista que consolidou a escorreita apreciação de práticas empresariais nocivas vigentes no ambiente econômico, as quais preteritamente divagavam pela legislação nacional sem que se verificasse efetivamente um diploma concentrador amplo, que coadunasse desde a tipificação de condutas puníveis às sanções cabíveis e ao órgão disciplinador, bem como sua forma de atuação, tal qual se vislumbra neste diploma.

Esta evolução é indutiva de uma maior potencialidade do controle da atuação dos agentes no mercado, com vistas a se fazer valer as diretrizes constitucionais garantidoras da liberdade de atuação e de concorrência, o que ao mesmo tempo garante a tutela também do direito constitucionalmente defeso do consumidor uma vez que a efetiva orientação da atuação empresarial fomenta um concreto controle sobre os mecanismos de elucidação de preços para os bens comercializáveis, o que inegavelmente é reflexivo para o consumidor. Assim a dimensão do que seja manifestação do poder econômico e abuso do poder econômico encontra guarida no ordenamento jurídico vez que ele mesmo suscita as elementares a serem observadas com vistas à persecução de tal limite. Esta linha, no entanto, não é de fácil definição dado que deve ser aferida conforme o caso concreto, considerando-se todos os pressupostos analisados supra tais quais o mercado relevante, a disponibilidade de recursos do agente e a sua esfera de atuação, o que oportunamente garantirá a efetiva compreensão da manifestação abusiva do poder econômico do agente ou não, seguindo-se a punição que se queira cabível.

Deve-se ressaltar, porém, que o fenômeno da globalização adentra tal cenário causando instabilidade vez que na constância da atuação dos conglomerados internacionais suscitamse discussões tocantes a aplicabilidade das leis nacionais no que concerne a atuação empresarial destes empreendimentos. Eis assim que a elucidação de normas regulamentadoras de caráter supranacional no âmbito da OMC seria de irretorquível valia para a comunidade internacional vez que trariam efetivas soluções diante das possibilidades de conflito de leis internacionais, suscitando maior segurança jurídica nas relações de comércio

Esta deve ser, portanto, a bandeira a ser levantada pelo Brasil no âmbito das suas relações exteriores diplomáticas de comércio, que concomitantemente a isto, enquanto não se consolide tal cenário, deve intentar tal conformação no âmbito do MERCOSUL, a fim de que as práticas comerciais do bloco possam ser norteadas por diretrizes comuns, a fim de se garantir maior segurança jurídica, que é de fundamental relevância no contexto atual de intempéries econômicas. 


\section{REFERÊNCIAS}

1. BANDEIRA DE MELlO. Celso Antonio. Curso de Direito Administrativo. $25^{\mathrm{a}}$ edição. São Paulo, Malheiros, 2008.

2. BRUNA, Sergio Varella. O poder econômico e a conceituação do abuso em seu exercício. $1^{\text {a }}$ Ed. São Paulo: Editora Revista dos Tribunais, 2001.

3. FAGUNDES, J. ; PONDÉ, J. Barreiras à Entrada e Defesa da Concorrência: Notas Introdutórias. Texto para Discussão $\mathrm{n}^{\circ} 1$, Cadernos de Estudo, Universidade Cândido Mendes, 1998.

4. GRAU, Eros Roberto. A Ordem Econômica na Constituição de 1988, $5^{\text {a }}$ ed., São Paulo, Malheiros, 2000.

5. ORAGNISATION FOR ECONOMIC CO-OPERATION AND DEVELOPMENTE. Disponível em: http://www.oecd.org/home/0,2987,en_2649_201185_1_1_1_1_1,00.html

Acesso em 10 de julho de 2009.

6. PASSOS, Carlos Roberto Martins; NOGAMI,Otto. Princípios de Economia. $4^{\mathrm{a}}$ Ed. São Paulo: Pioneira Thomson Learning, 2003.

7. SILVA, Plácido. Vocabulário Jurídico. 19ª ed. Rio de Janeiro: Forense, 2002.

8. SOUZA, Washington Peluso Albino de. Primeiras linhas de Direito Econômico. $6^{\mathrm{a}}$ Ed. São Paulo: LTr, 2005.

9. UNITED NATIONS CONFERENCE AND TRADE DEVELOPMENT. Disponível em: http://www.unctad.org/Templates/StartPage.asp?intItemID=2068 Acesso em 14 de julho de 2009.

10. VIEIRA, Liszt. Cidadania e globalização. $4^{\text {a }}$ Ed. Rio de Janeiro, Record, 2000. 